NBER WORKING PAPER SERIES

\title{
MUGHAL DECLINE, CLIMATE CHANGE, AND BRITAIN'S INDUSTRIAL ASCENT: AN INTEGRATED PERSPECTIVE ON INDIA'S $18^{\mathrm{TH}}$ AND $19^{\mathrm{TH}}$ CENTURY DEINDUSTRIALIZATION
}

\author{
David Clingingsmith \\ Jeffrey G. Williamson \\ Working Paper 11730 \\ http://www.nber.org/papers/w11730
}

\author{
NATIONAL BUREAU OF ECONOMIC RESEARCH \\ 1050 Massachusetts Avenue \\ Cambridge, MA 02138 \\ November 2005
}

\begin{abstract}
We are grateful for advice and criticism from Leah Platt Boustan, William Clarence-Smith, Greg Clark, Ron Findlay, Bishnupriya Gupta, Peter Harnetty, Debin Ma, Patrick O’Brien, Kevin O’Rourke, Sevket Pamuk, Leandro Prados, Om Prakash, Ananth Seshadri, T. N. Srinivasan, Tirthanker Roy, Tony Venables, and participants in the Harvard Economic History Tea, the 5th World Cliometrics Conference (Venice: June 2004), the Stockholm School of Economics (Stockholm: October 2004), and the GEHN Conference on Imperialism (Istanbul: September 2005). We also thank Javier Cuenca Esteban and Bishnupriya Gupta for sharing their data. Clingingsmith acknowledges support from the Project on Justice, Welfare, and Economics at Harvard University. Williamson acknowledges support from the National Science Foundation and from the Harvard Faculty of Arts and Sciences. The views expressed herein are those of the author(s) and do not necessarily reflect the views of the National Bureau of Economic Research.
\end{abstract}

(C)2005 by David Clingingsmith and Jeffrey G. Williamson. All rights reserved. Short sections of text, not to exceed two paragraphs, may be quoted without explicit permission provided that full credit, including () notice, is given to the source. 
Mughal Decline, Climate Change, and Britain's Industrial Ascent: An Integrated Perspective on India's $18^{\text {th }}$ and $19^{\text {th }}$ Century Deindustrialization

David Clingingsmith and Jeffrey G. Williamson

NBER Working Paper No. 11730

November 2005

JEL No. F1, N7, O2

\begin{abstract}
India was a major player in the world export market for textiles in the early 18 th century, but by the middle of the 19th century it had lost all of its export market and much of its domestic market. India underwent secular deindustrialization as a consequence. While India produced about 25 percent of world industrial output in 1750, this figure had fallen to only 2 percent by 1900 . We ask how much of India's deindustrialization was due to local supply-side forces -- such as political fragmentation in the 18th century and rising incidence of drought between the early 18 th and 19th century, and how much to world price shocks. We use an open, three-sector neo-Ricardian model to organize our thinking about the relative role played by domestic and foreign forces. A newly compiled database of relative price evidence is central to our analysis. We document trends in the ratio of export to import prices (the external terms of trade) from 1800 to 1913 , and that of tradable to non-tradable goods and own-wages in the tradable sectors back to 1765 . Whether Indian deindustrialization shocks and responses were big or small is then assessed by comparisons with other parts of the periphery.

David Clingingsmith Department of Economics Harvard University Cambridge, MA 02138 clinging@ fas.harvard.edu
\end{abstract}

Jeffrey G. Williamson

Department of Economics Harvard University

Cambridge, MA 02138

and NBER

jwilliam@fas.harvard.edu 


\section{Introduction}

The idea that India suffered deindustrialization during the $19^{\text {th }}$ century has a long pedigree. The image of skilled weavers thrown back on the soil was a powerful metaphor for the economic stagnation Indian nationalists believed was brought on by British rule. However, whether and why deindustrialization actually happened in India remains open to debate. Quantitative evidence on the overall level of economic activity in $18^{\text {th }}$ and $19^{\text {th }}$ century India is scant, let alone evidence on its breakdown between agriculture, industry, and services. Most deindustrialization assessments rely on very sparse data on employment and output shares. Data on prices are much more plentiful, and, as a consequence, this paper uses newly compiled evidence on relative prices to offer a new (price dual) assessment of deindustrialization in $18^{\text {th }}$ and $19^{\text {th }}$ century India. A simple neoRicardian model of deindustrialization links relative prices to employment shares. We think the paper sheds new light on whether and when deindustrialization happened, whether it was more or less dramatic in India than elsewhere, and its likely causes.

The existing literature primarily attributes India's deindustrialization to Britain's productivity gains in textile manufacture and to the world transport revolution. Improved British productivity, first in cottage production and then in factory goods, led to declining world textile prices, making production in India increasingly uneconomic (Roy 2002). These forces were reinforced by declining sea freight rates which served to foster trade and specialization for both Britain and India. As a result, Britain first won over India's export market and eventually took over much of its domestic market as well. This explanation for deindustrialization was a potent weapon in the Indian nationalists' critique of colonial rule (see e.g. Dutt 1906/1960; Nehru 1947). Like the first, a second explanation for India's deindustrialization also has its roots in globalization forces: India's commodity export sector saw its terms of trade relative to textiles improve significantly in the late $18^{\text {th }}$ century and it drew workers away from textiles. The historical literature also suggests a third explanation for deindustrialization coming from the supply side. We believe the economic malaise India suffered following the dissolution of Mughal hegemony in the $18^{\text {th }}$ century ultimately led to aggregate supply-side problems for Indian manufacturing, even if producers in some regions benefited from the new order. In addition, India suffered a secular deterioration in climate conditions in the century or so following the early 1700 s. We believe 
these added to the slump in agricultural productivity, to the rise in grain prices, and thus to deindustrialization. We will argue that these explanations are complementary and that each makes a contribution to our overall understanding of India's deindustrialization experience.

Before proceeding to our argument and evidence, we first offer a precise definition of deindustrialization and elaborate on its likely causes. We develop some initial intuition using a simple 2-good 3-factor framework. Suppose an economy produces two commodities: agricultural goods, which are exported, and manufactured goods, which are imported. Suppose it uses three factors of production: labor, which is mobile between the two sectors; land, which is used only in agriculture; and capital, which is used only in manufacturing. Suppose further that this economy is what trade economists call a "small country" that takes its terms of trade as exogenous, dictated by world markets. Given these assumptions, deindustrialization can be defined as the movement of labor out of manufacturing and into agriculture, either measured in absolute numbers (what we call strong deindustrialization), or as a share of total employment (what we call weak deindustrialization).

While deindustrialization is easy enough to define, an assessment of its short and long run impact on living standards and GDP growth is more contentious and hinges on the root causes of deindustrialization. One possibility is that a country deindustrializes because its comparative advantage in the agricultural export sector has been strengthened by productivity advance on the land at home or by increasing openness in the world economy, or both. Under this scenario, GDP increases in the short-run. If productivity advance on the land is the cause, nothing happens to the terms of trade unless the small country assumption is violated, in which case they deteriorate. If increased openness is the cause, the country enjoys an unambiguous terms of trade improvement as declining world trade barriers raise export prices and lower import prices in the home market. Whether real wages also increase depends on the direction of the terms of trade change and whether the agricultural good dominates workers' budgets. Whether GDP increases in the long run depends on whether industry generates accumulation and productivity externalities that agriculture does not. If industrialization is a carrier of growth — as most growth theories imply — then deindustrialization could lead to a growth slowdown and low-income equilibrium. The possibility that deindustrialization induced by increased openness in the world economy could engender low growth over the long run provides one potential explanation of the 
divergence in income between countries that characterized the $19^{\text {th }}$ and first half of the $20^{\text {th }}$ centuries (Maddison 2001), and accounts for the much of the power that deindustrialization has had in both the politics and the historiography of countries affected by it.

A second possibility is that a country deindustrializes due to deterioration in home manufacturing productivity and/or competitiveness. In this case, and still retaining the small country assumption, nothing happens to the terms of trade, but real wages and living standards will deteriorate, and so will GDP. The economic impact of deindustrialization from this source is unambiguous, and similarly carries the possibility of a low-growth equilibrium.

In order to make this theoretical framework flexible enough to handle the causes of deindustrialization we believe most important, we need to add a non-tradable grain sector. The three sectors considered in the rest of the paper are: agricultural commodity exports, which are tradable on world markets and include industrial intermediates (such as raw cotton and jute) and high-value consumer goods (such as opium and tea); manufacturing, which is dominated by textiles and metal products and is also tradable; and grains, which are non-tradable and include rice, wheat and other food staples. ${ }^{1}$

We will build up our account of India's deindustrialization as follows. In Section 2 we present a theoretical narrative of India's deindustrialization experience, drawing on evidence from the historical literature. Section 3 reviews existing attempts to measure India's deindustrialization. We then present a simple, neo-Ricardian, general equilibrium model of deindustrialization in Section 4 to formalize our predictions about relative prices and their relationship to employment shares. Section 5 presents three price series - commodity agricultural exports $\left(\mathrm{p}_{\mathrm{C}}\right)$, manufactured textiles $\left(\mathrm{p}_{\mathrm{T}}\right)$ and non-tradable grains $\left(\mathrm{p}_{\mathrm{G}}\right)$, three intrasectoral terms of trade series $-\mathrm{p}_{\mathrm{C}} / \mathrm{p}_{\mathrm{T}}, \mathrm{p}_{\mathrm{C}} / \mathrm{p}_{\mathrm{G}}$ and $\mathrm{p}_{\mathrm{T}} / \mathrm{p}_{\mathrm{G}}$, three wage series - the grain wage $\left(\mathrm{w} / \mathrm{p}_{\mathrm{G}}\right)$, the own-wage in the import competing sector $\left(\mathrm{w} / \mathrm{p}_{\mathrm{T}}\right)$, and the own-wage in the export sector $\left(\mathrm{w} / \mathrm{p}_{\mathrm{C}}\right)$, and the external terms of trade $\left(\mathrm{p}_{\mathrm{C}} / \mathrm{p}_{\mathrm{T}}\right)$. We will then assess this evidence in relation to the theoretical narrative, and also compare the relative price experience of India with its primary competitor during this period, England. Section 6 compares India's deindustrializing terms-of-trade shocks with those from other parts of the periphery, and section 7 concludes.

\footnotetext{
${ }^{1}$ Grains became tradable commodities throughout Asia in the late $19^{\text {th }}$ century, but for the $18^{\text {th }}$ and early $19^{\text {th }}$ century, it seems more accurate to treat them as non-tradables.
} 


\section{A Narrative Account of India's Deindustrialization}

Our narrative account of India's deindustrialization embraces the three contending deindustrialization hypotheses, and traces the roots of deindustrialization well back into the $18^{\text {th }}$ century. Two continent-wide political changes ground our understanding of India's $18^{\text {th }}$ century: The dissolution of the Mughal empire into a constellation of small successor states followed after a time by the initial phase of reintegration of these states under the East India Company. Historians have long thought that India underwent an overall economic decline during the $18^{\text {th }}$ century, following the collapse of Mughal authority. This proposition has recently become controversial, and we will stake out our position in favor of it below. We believe the political fragmentation of the $18^{\text {th }}$ century engendered a decline in agricultural productivity that was reinforced by a devastating climatic shift, a steep upward trend in the frequency of droughts. ${ }^{2}$ We start with the Mughal collapse hypothesis, and then turn to the climate hypothesis.

\section{The Mughal Collapse Hypothesis}

The dissolution of Mughal hegemony could have affected manufacturing through several channels.

The first is a reduction in overall agricultural productivity through an increased rent burden, shifting of settlement owing to insecurity, and warfare. Reduced agricultural productivity would be reflected in an increase of the price of grain, the key non-tradable, and therefore in the relative price of non-tradeables to tradables (such as textiles). ${ }^{3}$ To the extent that grain was the dominant consumption good for workers and that the grain wage was close to subsistence, this negative productivity shock should have put upward pressure on the nominal wage in cotton spinning and weaving. Cotton textile wages started from a low nominal but high real base in the mid-18th century (Parthasarathi 1998; Allen 2001). Competitiveness in textile manufacturing is negatively related to the own real wage $\mathrm{w} / \mathrm{p}_{\mathrm{T}}$, the nominal wage divided by the price of textiles. Declining textile prices and rising nominal wages put downward pressure on "profits" from both below and above. An

\footnotetext{
${ }^{2}$ Some have argued that deteriorating weather conditions helped precipitate the collapse of the Mughal Empire (Grove and Chappell 2000: 15), but the alleged connection is not central to our analysis.

${ }^{3}$ We assume that India was a price taker for textiles and other manufactures. Given this assumption, domestic demand did not matter in determining the performance of Indian industry. Only price and competitiveness on the supply side mattered.
} 
increase in the own wage in textiles would have hurt the edge India had relative to its $18^{\text {th }}$ century competitors in third-country export markets, such as the booming Atlantic economy. ${ }^{4}$ A decline in $18^{\text {th }}$ century agricultural productivity in India would suggest that even before factory-driven technologies appeared between 1780 and 1820, Britain was already beginning to wrest away from India its dominant grip on the world export market for textiles. $^{5}$

We are not the first to exploit the connection between labor productivity in pre-industrial agriculture, nominal wages in manufacturing, and the resulting competitiveness in world markets for manufactures.

Alexander Gerschenkron (1962) and W. Arthur Lewis (1978: chp. 2) both used the argument to good effect in explaining why low productivity in agriculture helps explain the absence or delay of industrial revolutions. More recently, Prasannan Parthasarathi (1998) has argued that while low nominal wages in pre-colonial and early colonial India gave it the edge in world textile markets, living standards for labor in the south of India were just as high as that in the south of England. Indian productivity was higher in food grain production, and thus food grain prices were lower.

Historians have traditionally viewed India's $18^{\text {th }}$ century as a dark era of warfare, political chaos, and economic decline sandwiched between stable and prosperous Mughal and British hegemonies. This view has been vigorously challenged by the most recent generation of Indian historians, who have emphasized the continuities between the earlier Mughal and later British states and the constellation of small successor states that emerged with the ebbing of Mughal power (e.g. Alam 1986; Bayly 1983; Marshall 1987). The largest of these successor states were the former Mughal provinces of Bengal, Awadh, Benaras, and Hyderabad. There were many smaller ones as well. Their rulers were former provincial governors, Mughal officials, and other

Thus, we ignore as irrelevant any argument which appeals to a rise in the demand for cloth as per capita income rose (Harnetty 1991: 455, 506; Morris 1983: 669).

${ }^{4}$ English merchants and English ships were the main suppliers to the Atlantic trade, a lot of it the so-called re-export trade. The share of Indian textiles in the West African trade was about 38 percent in the 1730 s, 22 percent in the 1780 s and 3 percent in the 1840s (Inikori 2002: 512-3 and 516). By the end of the 17 ${ }^{\text {th }}$ century, Indian calicos were a major force in European markets (Landes 1998: 154). For example, the share of Indian textiles in total English trade with southern Europe was more than 20 percent in the 1720 s, but this share fell to about 6 percent in the 1780 s and less than 4 percent in the 1840s (Inikori 2002: 517). India was losing its world market share in textiles during the $18^{\text {th }}$ century, long before the industrial revolution.

${ }^{5}$ To make matters worse, India, which had captured a good share of the English market in the $17^{\text {th }}$ century, had -- as an English defensive response -- already been legislated out of that market by Parliamentary decree between 1701 and 1722 (Inikori 2002: 431-2), thus protecting local textile producers. But Parliament kept the Atlantic economy as a competitive 
men powerful enough to assert de facto sovereignty. They collected the land revenue, sometimes using a modification of the old Mughal system, but submitted less and less of it to Delhi in favor of building up their own armies and courts.

While it has been widely accepted that the successor states provided a greater degree of political continuity and stability than was previously thought to have existed, no consensus has been reached about the implications of this fact for overall course of the continental Indian economy in the $18^{\text {th }}$ century. Marshall (2003) brings together contributions from the contending scholars and provides a useful overview. Where the $18^{\text {th }}$ century economy is concerned, some see the literature on the successor states as a useful corrective but believe the overall picture is one of decline. Others believe the traditional view to be fully overturned and view the $18^{\text {th }}$ century as a period of continued growth, despite the ebbing of Mughal hegemony. Two key differences between these views concern, first, the implications of the emergence of a new prosperity for the principal towns and middle classes of the successor states, and second, the degree of centralization and stability provided by the Mughal regime before its collapse, and thus the relative effect of the subsequent decentralization of power.

We tend to agree with the position that sees an aggregate economic decline following the dissolution of a strong empire into contending states. We believe that the more optimistic narrative tends to place too much emphasis on the prosperity of a few areas and groups, such as the towns of the successor states and their middle classes, and too little emphasis on the evidence for decline in the rural areas and peripheries of these states. Even in an era of aggregate economic decline, we would expect local booms to result from the diversion of land revenue flows from Delhi to the big towns of the successor states, where the new rulers and their revenue farmers lived. Moreover, the rural, agricultural sector was overwhelmingly dominant in the $18^{\text {th }}$ century Indian economy, ${ }^{6}$ so it is the economic performance of that sector which will largely dictate the course of the overall economy, not what happens in the towns. ${ }^{7}$ The optimistic narrative also seems to overly discount

free trade zone. Of course, the large Indian Ocean market was also a free trade zone, and India had dominated this for centuries (Chaudhuri 1978; Landes 1998: 154).

${ }^{6}$ Agriculture employed 68 percent of the Indian labor force even as late as 1901 (Roy 2002: 113).

${ }^{7}$ Since we take grain to have been non-tradable internationally, any secular tendency for domestic demand to outpace domestic supply would have raised grain prices. An exogenous acceleration of population growth would have lowered labor productivity on the land, reduced food supply relative to demand, and thus raised the price of food. However, population grew at only 0.26 percent per annum between 1700 and 1820 , and this was only a trivial increase over what 
the strength of the Mughal empire and the economically favorable stability it brought. The Mughal state shows evidence of having achieved a high level of centralization and control of revenue sources. Revenue realization per cultivated acre was as high in remote provinces as in the center. Examination of the careers of Mughal revenue officials shows that provincial postings were of virtually the same duration (about two and a half years) all over the empire, suggesting that remote provinces were well integrated into the imperial machinery (Habib 2003). There do not appear to have been many Mughal officials who were in reality local potentates. An imperial regime powerful enough to extract 40 percent of the economic surplus from distant provinces must have also insured peace and security, which are in turn favorable for agricultural investment and productivity.

Our evidence for an overall $18^{\text {th }}$ century economic decline begins with an examination of unskilled wages in grain units, which are a good measure of the overall level of economic activity in a largely agricultural economy. Figure 1 presents three grain-wage series, two from North India and one from South India, from Radhakamal Mukerjee (1939) and Stephen Broadberry and Bishnupriya Gupta (2005). This figure documents a long-run decline in grain wages beginning in the last decades of the $17^{\text {th }}$ century and continuing until late in the $18^{\text {th }}$ century. ${ }^{8}$ We believe it is important to realize that even though the wage and price data for early modern India are thin, they provide us with one of the few indicators of the condition of ordinary people and the aggregate economy that is easily compared across time. We believe a number of features of the transition of political authority from the Mughal empire to the successor states provide further evidence supporting an overall economic decline, and moreover one that resulted from reduced agricultural productivity. We find Christopher Bayly's view of $18^{\text {th }}$ century north India particularly compelling, as it is shows how urban prosperity coexists with aggregate agricultural decline (Bayly 1983).

As central Mughal authority waned, the state resorted increasingly to revenue farming, and the practice became even more widespread in the successor states. This served to raise the effective rent share to 50 percent or more, greater than the 40 percent maximum said to have been extracted by the Mughal state

preceded it (Moosvi 2000: 322). Thus, we believe other forces would have to explain any observed rise in the relative price of grains. 
(Raychaudhuri 1983: 17; Bayly 1983: 10). "With revenue assessment geared to 50 per cent or more, in contrast to China's 5 to 6 per cent, the Indian peasant had little incentive to invest labour or capital" (Raychaudhuri 1983: 17). The economics is familiar to development economists, economic historians, and observers of modern agrarian backwardness: The lower the share of output received by the peasant, the less incentive he has to be productive, to carefully monitor the crop, to invest in land, and to remain in place rather than fleeing. Scattered evidence suggests that the rent burden may have been quite extreme in some locations (Bayly 1983: 42). In the Rohilla state north of Delhi, cultivators were stripped of their land rights entirely and reduced to direct dependence. Under the savak system in north Awadh, cultivators received as little as one sixth of the produce and their wives and children were required for corvée for a large part of the year. The Sayyids of Moradabad employed the batai system in which they "appropriated all 'save a bare subsistence' from the cultivators and invaded the villages for several months a year with bullock teams, armed retainers, and weighmen to secure the best portion of the crop." Productivity must have suffered as a result of the increased rent burden. Tapan Raychauduri claims the grain prices "increased by 30 percent or more in the $1740 \mathrm{~s}$ and $1750 \mathrm{~s}$ " as a result (Raychaudhuri 1983: 6). There is no reason to believe that when the British became rulers of the successor states the revenue burden declined. Initially at least, British revenue officials saw slack in the existing system more often than not, and increased the revenue burden.

Rulers of the successor states also engaged in territorial disputes, and it is possible the increased rent burden reflected military expenses. These wars drew key resources out of agriculture and also led to the destruction of capital:

"Endemic local warfare ... and the collapse of local aristocracies had effects which were inimical to agricultural production ... Cultivation was driven back from the roads by the passage of marauding armies who sometimes deliberately destroyed walls and irrigation tanks" (Bayly 1983: 70).

Areas at the edges of successor states were particularly prone to agricultural decline, perhaps because these were most affected by territorial disputes, both between states and between local strongmen, who in remote areas were relatively free to plunder their neighbors. This led to population shifts as cultivators retreated to more secure areas. Bayly describes "large penumbras of agricultural decline, particularly in the northwest" $(1983,76)$. However, he 
believes that increases in input prices were even more significant than the withdrawal of some areas from cultivation:

"More important, warfare withdrew both men and animals from agriculture ... Recruitment into armies, the consolidation of population into defensive centers, and general migration ... contributed to a patchy and local decline in cultivated area. Draught animals determined the extent of cultivation even more than human labor, and there is scattered evidence of a great dearth of animal power in north central India" (Bayly 1983: 70-1).

A dearth of animal power would certainly have led to less efficient cultivation techniques and increased prices. Cultivators who relied on the bullocks owned by others would have been particularly vulnerable to fluctuations in their availability due to warfare. To cite an example, when Ahmed Shah Durrani invaded India from the northwest in 1759, bullock hire rates between Benares and Patna, a route nearly $600 \mathrm{~km}$ from the furthest extent of the fighting, increased by 500 percent (Bayly 1983: 68). This suggests the agricultural economy was operating on very inelastic regions of the supply and/or demand curves for these key inputs, which is suggestive of a shortage. Political fragmentation and warfare also disrupted India's major internal trade routes, and likely increased transport costs and insurance. Since most long distance transport was by bullock, the scarcity of bullock power resulting from warfare would have increased transport costs. Irfan Habib (2003) also presents fragmentary evidence that insurance rates may have gone up during the $18^{\text {th }}$ century.

We therefore find credible Holwell's claim that the dissolution of the Mughal empire led to "a scarcity of grains in all parts, [and] the wages of labour [were] greatly enhanced," even if other aspects of the traditional view of $18^{\text {th }}$ century India have been discredited (Holwell 1766-1767, cited in Raychaudhuri 1983: 6). This presumed rise in nominal wages would have slowly eroded the long-standing source of Indian $17^{\text {th }}$ and $18^{\text {th }}$ century competitiveness in foreign textile markets, long before Britain flooded those markets with factory-made products, and declining agricultural productivity in India must have been at the heart of it. After 1800, Indian "textile exports ... could not withstand the competition of English factory-produced cottons in the world market" (Moosvi 2002: $341)$. 


\section{Climate, EI Niño and Agricultural Crisis}

There was another force at work that may also have served to lower agricultural productivity and raise grain prices in $18^{\text {th }}$ and early $19^{\text {th }}$ century India - El Niño, the periodic rise in Pacific sea surface temperature that can cause India's monsoon rains to fail. Charles Darwin stressed the influence of climate in The Origin of the Species: "Climate plays an important part in determining the average numbers of a species, and periodical seasons of extreme cold or drought seem to be the most effective of all checks" (1972: 72, italics added). Indeed, for some time now, climate historians have developed evidence documenting frequent and deep droughts in South Asia over the late $18^{\text {th }}$ and $19^{\text {th }}$ century (e.g. Grove 1997; Grove, Damodaran and Sangwan 1998; Grove and Chappell 2000) and modern Indian data clearly document the powerful role of rainfall on grain yields (Kapuscinski 2000).

Figure 2 presents a centered 50-year moving average of the occurrence of drought in India between 1550 and 1900. It includes archive-based drought data reported in Richard Grove and John Chappell (2000: Table 1) and culled from various sources (Habib 1977; Dyson 1989; and $19^{\text {th }}$ century publications). The pattern is striking. The average is close to 0.35 for the period $1550-1640$, or about one drought year every three. It then falls precipitously over a fifteen-year span to about 0.17 , or about one drought year every six. The statistic remains at this favorable level for the seventy years from 1655-1725. It then falls to an even lower level in $1735,0.10$, or one drought year every ten, before beginning a steep eighty year climb to over 0.40 in 1813 , or one drought year every two and a half.

India thus experienced a historically low rate of drought during the period 1650-1735, which corresponds to the Mughal Empire's golden age under Shah Jahan and its overextension and collapse under Aurangzeb. Shah Jahan's reign was the height of Mughal opulence, and he built the Taj Mahal at Agra and the Lal Quila at Delhi. Aurangzeb by contrast was austere, and loved conquest more than luxury (Wolpert 1989). The Mughals increased the territory under their control by about half during the reigns of Shah Jahan and Aurangzeb, moving deep into southern and western India. The Empire reached its territorial maximum at

around the end of the $17^{\text {th }}$ century, when only the very southern tip of the subcontinent was excluded (O'Brien 1999). The last decades of Aurangzeb's life were spent trying to subdue the tenacious Marathas in western India, at great cost in both blood and treasure. During the fractious succession following Aurangzeb's death in 
1707, the Marathas surged out of their Deccan strongholds, extending their control across almost a third of India by 1757 . The low drought occurrence during these years must have augmented agricultural productivity and thus the resources available for the conquest of vast territories by the Mughals and the Marathas. These unusually good climatic conditions soured in 1735 , when India was politically fragmented and conflict widespread, thus making an increasingly bad agricultural situation worse.

All of this evidence suggests that a worsening climate may have reinforced the impact of the Mughal Empire's decline on agricultural productivity. The combined influence of drought and the disintegration of the Mughal Empire on diminishing grain yields in the second half of the $18^{\text {th }}$ and early $19^{\text {th }}$ century can be inferred from various fragmentary sources. For example, the evidence documenting deserted villages in rural Tamil Nadu in southern India (Lardinois 1989: 34-43) reveal very high rates between 1795 and 1847, but they were more than twice as high in 1795-1814 (21.4 percent) than 1816-1847 (10.1 percent). Indeed, the worst El NiZo episode in written history was probably 1791 :

"Already devastated by a famine in 1780 the Circars of the Madras Presidency were again very badly affected by drought in 1789-1792 and many villages in the Godavery delta were entirely depopulated. [One observer] later reported that 'owing to a failure of rain ... one half of the inhabitants in the Northern Circar had perished in famine and the remainder were so feeble and weak that on report of rice coming up from the Malabar coast five thousand people left Rajahmundry and very few of them reached the seaside, although the distance is only fifty miles"” (Grove 1997: 134).

This evidence certainly suggests low and falling agricultural productivity in the second half of the $18^{\text {th }}$ and the early $19^{\text {th }}$ century, but we think that the best evidence of poor agricultural conditions in India was the soaring relative price of grains, evidence which we will discuss at length later in this paper.

\section{A Deindustrialization Offset: The Financial Drain}

Even if we had good data on Indian employment and output in the $18^{\text {th }}$ and early $19^{\text {th }}$ centuries, deindustrialization effects could be difficult to discern between 1772 and 1815 , because during that period there was a huge net financial transfer from India to Britain that was matched by a net transfer of Indian goods. The "drain resulting from contact with the West was the excess of exports from India for which there was no 
equivalent import" (Furber 1948: 304), including "a bewildering variety of cotton goods for re-export or domestic [consumption], and the superior grade of saltpeter that gave British cannon an edge" (Cuenca Esteban 2001: 65). Indian textiles were at this time an important vehicle by which Britons repatriated wealth accumulated in India to England, increasing demand for them. Javier Cuenca Esteban estimates these net financial transfers from India to Britain reached a peak of $£ 1,014,000$ annually in 1784-1792 before declining to $£ 477,000$ in $1808-1815$ and $-£ 77,000$ in 1816-1820 (Cuenca Esteban 2001: Table 1, line 20). However, at their peak in 1784-1792, these net Indian transfers still amounted to less than 2 percent of British industrial output (Deane and Cole 1967: Table 37, 166, using 1801 "manufacture, mining, building"). As a share of Indian industrial output, these net transfers were probably about the same. ${ }^{9}$ Thus, while a secular fall in the “drain" after the 1784-1792 peak must have served to speed up the pace of deindustrialization in early $19^{\text {th }}$ century India by reducing demand for Indian textiles, the effect could not have been big. There must have been other fundamentals at work that mattered far more.

\section{The $19^{\text {th }}$ Century Globalization Hypothesis: Britain Did It}

Around the beginning of the $19^{\text {th }}$ century, the fundamental economic dynamic underlying deindustrialization in India changed from agricultural productivity decline to globalization shocks. Globalization is the most popular explanation for India's deindustrialization in the literature, and it is an important component of the historiography of colonial India constructed by the Indian nationalists. For example, Jawaharlal Nehru's classic Discovery of India (1947) argued that India became progressively ruralized in the $19^{\text {th }}$ century owing to the destruction of artisanal employment by British factory-made goods. Nehru laid the blame squarely on colonial economic policy, which almost entirely eschewed tariff protection and did nothing to help nurture Indian industry (Nehru 1947: 247-53). Similar arguments can be found in the work of the $19^{\text {th }}$ century nationalist Dadabhai Naoroji, pioneering Indian economic historian R.C. Dutt, and the Marxist historian D.D. Kosambi.

\footnotetext{
9 Maddison (2001: 184 and 214) estimates that in 1820 the GDP of the India (including present-day Bangladesh and Pakistan) was about three times that of the United Kingdom, but the industrial share must have been a lot smaller in India. The text assumes that these offsetting forces were roughly comparable.
} 
The economic logic underlying the deindustrialization-through-globalization hypothesis is that rapid productivity advance in European manufacturing — led by Britain — lowered the relative price of textiles, metal products and other manufactures in world markets. The European industrial leaders shared those productivity gains with the rest of the world as augmented world supplies of manufactures lowered world prices. Having first defeated India in its export markets, "after 1813 Lancashire invaded India as well” (Moosvi 2002: 341). Cheap British factory-made yarn and cloth took away India's local market from her own producers. India experienced deindustrialization over the half century following 1810 due to terms-of-trade shocks in its favor. The relative price impact of the unbalanced productivity performance is best illustrated by trends in Britain's terms of trade. According to Albert Imlah, they fell by 40 percent over the four decades between 1801-1810 and 1841-1850 (Mitchell and Deane 1962: 331). That is, the price of British exports (manufactures) fell dramatically compared with that of its imports (industrial intermediates, food and other primary products). India's textile producers - already well integrated into the world textile market—faced a big negative price shock on that score alone. Failing to keep up with the factory-based productivity growth achieved abroad, the Indian textile industry took the price hit, became less profitable, and deindustrialization ensued. As if this were not enough, the foreign-productivity-induced negative price shock was reinforced by another powerful global event. Trade barriers between India and her foreign markets declined, particularly due to the transport revolution (Shah Mohammed and Williamson 2004) but also due to tariff policy. The relative supply price of manufactures in India was driven down still further, and it was driven down even more compared with Indian exports, since overseas transport improvements served to raise export prices in the home market. These world market integration trends served to create "Dutch disease" effects in India: The import-competing sectors slumped, the export sectors boomed, and deindustrialization was reinforced.

The decline in world textile prices caused by British productivity advance made textile production in India less attractive relative to Britain. It also contributed to a shift in the terms of trade between India's own textiles and agricultural commodity export sectors, a shift reinforced by booming world demand for Indian agricultural commodities. This shift alone would have caused a decline in the relative employment in textiles. The most important agricultural commodities for India in the first half of the $19^{\text {th }}$ century were opium, raw cotton, raw silk, and sugar, and they were a growing fraction of India's exports. By 1811, they accounted for 
57 percent of India's exports by value, compared to 33 percent for cotton piecegoods (Chaudhuri 1983). The role played by the terms of trade in reallocating resources to commodity agriculture is noted in the literature on the commercialization of Bengali agriculture in the late $18^{\text {th }}$ century (Chowdhury 1964), but it has not yet been a part of the deindustrialization debate.

In sum, our view is that the long run sources of India's deindustrialization were both the globalization price shocks due to European productivity advance in manufacturing (and the induced demand for industrial intermediates such as cotton and indigo) plus the negative productivity shocks to Indian agriculture induced by the earlier Mughal decline and deteriorating climate conditions. ${ }^{10}$ We do not see these foreign and domestic effects as competing. They were both at work, and they reinforced each other, although each had its most important influence in different epochs.

\section{Measuring India's Deindustrialization}

\section{Inputs, Outputs, and Deindustrialization}

Despite its importance for Indian historiography, owing to the dearth of statistical sources there have been only four attempts to directly measure India's $19^{\text {th }}$ century deindustrialization experience by trying to construct employment shares. We believe we are the first to apply relative price evidence to the deindustrialization question, and by doing so the first to offer evidence, tentative though it may be, about deindustrialization in the $18^{\text {th }}$ and early $19^{\text {th }}$ century. Tirthankar Roy (2000) offers a useful survey of the existing direct evidence, starting with this big fact: It seems likely that the share of the work force engaged in industry was quite a bit higher in 1800 (probably 15-18 percent) than it was in 1900 (about 10 percent). In the strictest sense, therefore, strong deindustrialization appears to have taken place over the $19^{\text {th }}$ century. However, the literature insists on some qualifications to this big deindustrialization fact. First, many workers who gave up industry over the century were working only part-time. Second, the import of machine-made goods only helps explain the demise of textiles. Finally, cheaper imported cloth would have benefited

\footnotetext{
${ }^{10}$ Peter Harnetty would appear to agree, although he was speaking of the Central Provinces in the $1860 \mathrm{~s}$, after our century of interest starting roughly with 1750. Harnetty says (1991: 460): "The combination of high food prices and cheap cloth imports had a depressing effect on the local industry."
} 
consumers. All of these qualifications make good sense. ${ }^{11}$ In addition, the literature stresses that there was a rise in employment in indigo, opium, and saltpeter, but these became major commodity exports, not industrial goods.

The first evidence supporting strong deindustrialization was offered more than a half century ago by Colin Clark (1950). Clark published tabulations of the 1881 and 1911 Census of India showing that the share of the Indian workforce in manufacturing, mining, and construction declined from 28.4 to 12.4 percent from 1881 to 1911 , implying dramatic deindustrialization in the late $19^{\text {th }}$ century. Daniel Thorner $(1962)$ reexamined the Census data and convincingly argued that the tabulations used by Clark were misleading. His revised estimates show that the sectoral employment structure was stationary after 1901, with only a very small decline in male non-agricultural employment between 1881 and 1901. Thorner used these revisions to make two important points. First, if there was a major shift out of industry and into agriculture, it occurred before 1881, not after. Indeed, Om Prakash (2005: 28) reports that Indian textile employment fell by 3.6 million between 1850 and 1880. Second, if deindustrialization occurred after 1881, it was on a very modest scale, and all of it took place before 1901.

The third attempt to measure deindustrialization looks to the early $19^{\text {th }}$ century, closer to the years which anecdotal evidence has always suggested were those of most dramatic deindustrialization. ${ }^{12}$ Amiya Bagchi (1976a, 1976b) examined evidence on handloom spinning and other traditional industry in Gangetic Bihar, an area of eastern India, collected between 1809 and 1813 by the East India Company surveyor Dr. Francis Buchanan Hamilton. ${ }^{13}$ Bagchi compared Hamilton's data with the 1901 Census estimates of the population dependent on industry for the same area. His findings are presented in Table 1. The population dependent on industrial employment requires an estimate of family size, and Bagchi makes two estimates

\footnotetext{
${ }^{11}$ The literature also argues that cheaper imported yarn would have reduced the production costs facing handloom weavers, thus making them more competitive. Since cheaper European factory-produced yarn would have lowered the production costs not just for Indian handloom weavers but for weavers the world around, it is not clear how this made Indian weavers more competitive with imported cloth.

${ }^{12}$ Among the most well known examples is the powerful image quoted by Karl Marx in Das Kapital: "The misery hardly finds a parallel in the history of commerce. The bones of the cotton-weavers are bleaching the plains of India" (1977[1867], vol. 1: 558). Marx attributed this quote to the Governor-General of India in 1834-1835, who was Sir William Bentinck. However, Morris D. Morris has pointed out that the quoted words do not appear in Bentinck's report of that year or in his papers (Morris 1969: 165, n.152). The true source of this first report of deindustrialization remains a mystery. ${ }^{13}$ Hamilton spent nearly \$20 million (2005 US\$) on the survey, and his information appears to be of high quality (Martin 1838).
} 
using altenative assumptions. Under Assumption A, each spinner supports only him or herself, and under Assumption B, each spinner also supports one other person. Under both assumptions, non-spinners are assumed to support the survey's modal family size (five). He also removes commercial workers from the 1901 data to make them consistent with the 1809-13 data. Spinners in Gangetic Bihar were almost exclusively women who spun in the afternoons (Dutt 1960: 232-5). Hamilton's estimates show that women earned about Rs. 3.25 annually at spinning, while a male day laborer who worked 200 days would earn about Rs. 8 annually, all of which suggests that Assumption B is more likely to be true. In either case, Bagchi's evidence suggests a substantial decline in the industrial employment share during the $19^{\text {th }}$ century from more than 21 percent to less than 9 percent. When the Bagchi and Thorner evidence is combined, it suggests that most $19^{\text {th }}$ century deindustrialization took place during its first half.

While the employment share in "other industrial" occupations fell over the century as well, it is important to note that the largest component of deindustrialization was the decline of cotton spinning. ${ }^{14}$ Table 2 rearranges Bagchi's original numbers, making the contribution of cotton spinning to overall deindustrialization more transparent. Of the 12.7 percent of the population that depended on cotton weaving and spinning in 1809-1813, more than 80 percent depended on spinning. Since cotton spinning was performed part-time by women at home using extremely simple technology, it may seem implausible to argue that the demise of cotton spinning in the early $19^{\text {th }}$ century destroyed India's platform for modern industrialization. Yet British economic historians assign the same importance to home-based cotton spinning: $17^{\text {th }}$ and $18^{\text {th }}$ century "proto-industrial" cottage industries are said to have supplied the platform for the factory-based British industrial revolution that followed in the late $18^{\text {th }}$ century (Mokyr 1993: chps. 1-3). Furthermore, employment of women and children was central to the process then too (Mokyr 1993: chp. 1; De Vries 1994).

Finally, in an unpublished study reported by Habib (1985), Amalendu Guha calculated the amount of cotton yarn available for Indian handloom production by subtracting the quantity used in local machine production from total local yarn production and imports. The result documents a huge decline in yarn used for handloom production, from 419 million pounds in 1850, to 240 in 1870 and to 221 in 1900 . This indirect evidence suggests that the decline in hand spinning documented for Gangetic Bihar in the early $19^{\text {th }}$ century 
was widespread, that it was followed by a decline in hand weaving during the mid-century, and that the decline of both hand spinning and weaving was almost complete by 1870 . These facts are consistent with Peter Harnetty's summary characterization of Indian handloom weaving in the $19^{\text {th }}$ century:

"At the opening of the century, the handloom weavers had supplied all the textile requirements of the country and had maintained a flourishing export trade, notably to Britain [e.g. re-exports]. This reached its peak in value in 1800 and in volume in 1802, thereafter, imports of Indian piece goods to Britain declined sharply in face of competition from the growing British cotton industry." "From about 1840 ... British imports entered the [local] market in strength." "At the turn of the $\left[20^{\text {th }}\right]$ century, India was absorbing more than 40 per cent of total British cloth exports to the world" (Harnetty 1991: 472).

As we have argued, the trouble actually started over the half century before the 1800 peak with Britain's challenge to India's dominant presence in foreign markets.

Paul Bairoch (1982) used evidence similar to that reviewed above to assess deindustrialization not only in India, but across the non-European periphery. Table 3 reports Bairoch's survey. In 1750, China and India together accounted for 57 percent of world manufacturing output, while India itself accounted for about a quarter. By 1800, India's world share had already eroded to less than a fifth, by 1860 to less than a tenth, and by 1880 to less than 3 percent. Bairoch's investigation found that India's share in world manufacturing output declined precipitously in the half century 1750-1800, before factory-led industrialization took hold in Britain and consistent with our hypothesis that deindustrialization took place in the $18^{\text {th }}$ century. Furthermore, India's experience was different than that of China or the rest of the periphery. Between 1750 and 1830 India's world manufacturing output share dropped by 6.9 percentage points from a base of 24.5 percent, much bigger than the fall elsewhere (China lost 3 percentage points, and the rest of the periphery lost 2.4 percentage points). Bairoch's data suggest that during the century before 1830, well before European factories flooded world markets with manufactures, India suffered much more pronounced deindustrialization than did the rest of the periphery. This fact must be explained by domestic conditions in India, not shared by the rest of the periphery, fully consistent with our agricultural productivity hypothesis.

\footnotetext{
${ }^{14}$ The percent of industrial workers who were spinners fell from 82 to 15 between 1809-13 and 1901.
} 
World output shares can also change due to different rates of output growth across countries. The economic implications of faster growth abroad are much more benign than those of slow growth at home. Anticipating this criticism, Bairoch (1982: Tables 6 and 9) also documented that per capita levels of industrialization in India fell from an index of 7 in 1750 to 3 in 1860 and 2 in 1913. In contrast, Britain's per capita industrialization index rose from 10 in 1750 to 64 in 1860 to 115 in 1913.

\section{Real Wages and Deindustrialization}

Models of deindustrialization such as that of Paul Krugman and Anthony Venables (1995) suggest that it should be accompanied by a long run decline in real wages. The evidence for $18^{\text {th }}$ and $19^{\text {th }}$ century India is not yet of high quality, but it does document a secular deterioration.

Parthasarathi (1998) argues that real wages in mid-late $18^{\text {th }}$ century South India were comparable to those in the south of England, and thus that the rising living standard gap between the two was a late $18^{\text {th }}$ and early $19^{\text {th }}$ century phenomenon. Robert Allen (2001) uses Mughal manuscript sources to compute the real wage in 1595 Agra, then the capital of the Mughal Empire. He compares it to the real wage in 1961, based on a common market basket of consumer goods. Allen's evidence documents a fall in the real wage by about 23 percent over those 366 years, and if Parthasarathi is correct, most of that fall must have taken place after the mid-late $18^{\text {th }}$ century. Anthropometric evidence on south Indian indentured workers suggests that living standards stagnated during the last half of the $19^{\text {th }}$ century (Brannan et al. 1994). But perhaps the most telling evidence of real wage performance, and its timing, comes from Mukerjee (1939) and Broadberry and Gupta (2005), reproduced in Figure 1. Mukerjee reports 1600-1938 real wages in northern India of unskilled and skilled labor (nominal wage rates deflated by grain prices) starting with the same 1595 benchmark used by Allen. Broadberry and Gupta offer grain wages for both north and south India, with the most resolution in the $17^{\text {th }}$ and $18^{\text {th }}$ centuries. According to this evidence, by 1789 real wages had fallen $30-44$ percent from their 1600 level. By 1875, real wages were at only 25-50 percent of the 1600 level.

This evidence suggests that the vast majority of the real wage and living standards fall took place before 1850 , or even before 1825 , not after. Was deindustrialization responsible for the fall, and were the deindustrialization forces more powerful before 1850 , or even before 1807 , than after? The sparse data on 
employment and output shares suggests deindustrialization was an important force in the Indian economy during the $19^{\text {th }}$ century. This account can be supplemented and pushed back into the $18^{\text {th }}$ century with much richer relative price data, but before doing so we need to model the relationship between relative prices and deindustrialization.

\section{A Neo-Ricardian Model of Deindustrialization}

In order to formalize our intuitions about the relationship between relative prices and deindustrialization, we develop a simple neo-Ricardian model that relies on the classic contribution of Ronald Jones (1971). Consider a perfectly competitive economy in which there are three sectors: textiles (T), grain (G), and agricultural commodity exports (C). Grain is not traded. Agricultural commodity exports include nongrain items such as opium, tea, indigo, jute, and raw cotton. Textiles and agricultural commodities are traded in the world market and sell for the world prices $\mathrm{p}_{\mathrm{T}}$ and $\mathrm{p}_{\mathrm{C}}$, respectively. Labor $(\mathrm{L})$ is mobile between all three sectors, is the only factor of production, and costs nominal wage w per unit. We abstract from capital and land for simplicity, ${ }^{15}$ but in any case we do not need them to make our point.

To create a link between agricultural productivity and wages in the textile sector, which we believe was a key driver in India's loss of competitiveness in the $18^{\text {th }}$ century world textile market, we follow Lewis $(1954,1978)$ in assuming that the real wage in grain units is constant. This reflects the Malthusian assumption that in a poor country the supply of labor will be unlimited as long as the wage assures subsistence. Any lower wage leaves laborers unable to sustain the physical capacity for work. The Lewis assumption implies the possibility of unemployment, so L represents employment rather than the population, which we denote by $\mathrm{P}$.

Suppose output in each sector is produced according to a Cobb-Douglas production function:

$$
\begin{aligned}
& \mathrm{Y}_{\mathrm{G}}=\mathrm{GL}_{\mathrm{G}}{ }^{\alpha} \\
& \mathrm{Y}_{\mathrm{C}}=\mathrm{CL}_{\mathrm{C}}{ }^{\beta} \\
& \mathrm{Y}_{\mathrm{T}}=\mathrm{TL}_{\mathrm{T}}^{\gamma}
\end{aligned}
$$


$\mathrm{G}, \mathrm{C}$, and $\mathrm{T}$ are technology parameters and the elasticities $\alpha, \beta$, and $\gamma$ are all less than $1 .{ }^{16}$ The labor market is such that each individual will supply one unit of labor as long as the grain wage $\mathrm{w} / \mathrm{p}_{\mathrm{G}}$ is at or above the reservation price of 1 . We assume that there is no rationing of labor, so that $\mathrm{L}=\mathrm{L}_{\mathrm{G}}+\mathrm{L}_{\mathrm{C}}+\mathrm{L}_{\mathrm{T}}<\mathrm{P}$. Perfect competition in each sector ensures through zero-profit conditions that labor demand will be given by:

$\mathrm{L}_{\mathrm{G}}=\left(\mathrm{p}_{\mathrm{G}} \mathrm{G} / \mathrm{w}\right)^{(1 / 1-\alpha)}=\mathrm{G}^{(1 / 1-\alpha)}$

$\mathrm{L}_{\mathrm{C}}=\left(\mathrm{p}_{\mathrm{C}} \mathrm{C} / \mathrm{w}\right)^{(1 / 1-\beta)}$

$\mathrm{L}_{\mathrm{T}}=\left(\mathrm{p}_{\mathrm{T}} \mathrm{T} / \mathrm{w}\right)^{(1 / 1-\gamma)}$

If we assume that there is no technical change, the growth rates of labor demand are

$$
\begin{aligned}
& \mathrm{L}_{\mathrm{G}} *=0 \\
& \mathrm{~L}_{\mathrm{C}} *=-(1 / 1-\beta)\left(\mathrm{w}^{*}-\mathrm{p}_{\mathrm{C}} *\right) \\
& \mathrm{L}_{\mathrm{T}} *=-(1 / 1-\gamma)\left(\mathrm{w}^{*}-\mathrm{p}_{\mathrm{T}}{ }^{*}\right)
\end{aligned}
$$

Since the nominal wage is equal to the price of grain, employment in the grain-producing sector is fixed.

Growth in the own wage in either commodity agriculture or textiles leads to a decline in the absolute number of workers employed there. Thus, strong deindustrialization results from an increase in the own wage in textiles. The own wage in either sector could increase due to a decline in the world price for its output. It could also increase if the price of grain rose, for example from a negative productivity shock in agricultural production.

The growth rate of the share of textile workers in total employment, our measure of weak deindustrialization, is:

\footnotetext{
${ }^{15}$ For our period, reliable information on these factors and their returns are difficult to obtain for India.

${ }^{16}$ Constraining the elasticities to be less than one ensures that labor demand is finite. It also implies decreasing returns to scale. Adding specific factors to each sector would allow for constant returns, but would not change the intuitions we wish to draw from the model.
} 


$$
L_{T}^{*}-L^{*}=\frac{-1}{(1-\beta)(1-\gamma)}\left(\left[(1-\beta)\left(1-\theta_{T L}\right)\left(w^{*}-p_{T}{ }^{*}\right)\right]-\left[(1-\gamma) \theta_{C L}\left(w^{*}-p_{C}{ }^{*}\right)\right]\right)
$$

The shares of textiles and commodity agriculture in total employment are given by $\theta_{\mathrm{TL}}$ and $\theta_{\mathrm{CL}}$, respectively. Thus, weak deindustrialization will result whenever the own wage in textiles is growing sufficiently fast compared to the own wage in agricultural commodity exports. Moreover, holding employment shares constant, weak deindustrialization will be most severe when the difference in own wage growth rates is largest. More formally, the condition that must be satisfied for weak deindustrialization is

$$
w^{*}-p_{T}^{*}>\frac{(1-\gamma) \theta_{C L}}{(1-\beta)\left(1-\theta_{T L}\right)}\left(w^{*}-p_{C}^{*}\right)
$$

Given that both commodity agriculture and textile sectors are small shares of total employment in late $18^{\text {th }}$ and early $19^{\text {th }}$ century India, the ratio on the right-hand side is likely to be less than one. ${ }^{17}$ This implies that own wage growth in agricultural commodity exports would have to be even higher to counteract the weak deindustrialization effect of own wage growth in textiles. In short, we expect to see weak deindustrialization whenever own wage growth in textiles is positive, unless own wage growth in agricultural commodity exports is much greater. Own wage growth in agricultural commodity exports dampens the weak deindustrialization effect because it reduces $\mathrm{L}_{\mathrm{C}}$, which is in the denominator of our weak deindustrialization measure. As the share of the labor force employed in agricultural commodities increases, the greater growth in the own wage in textiles needs to be to overcome growth of the own wage in agricultural commodities and for deindustrialization to ensue. We can also rewrite condition (11) to relate nominal wage growth to the terms of trade between textiles and commodity agriculture.

\footnotetext{
${ }^{17}$ For example, let $\beta=\gamma$ and following Table 2 set $\theta_{\mathrm{TL}}=0.15$. If we assume $\theta_{\mathrm{CL}}=0.1$, then the ratio is 0.12 . For strong deindustrialization to occur, own wage growth in textiles must be about 0.12 times greater than own wage growth in agricultural commodities.
} 
$\frac{(1-\gamma) \theta_{C L}+(1-\beta)\left(1-\theta_{T L}\right)}{(1-\beta)\left(1-\theta_{T L}\right)} w^{*}>p_{T}^{*}-p_{C}{ }^{*}$

Weak deindustrialization results when nominal wage growth, which deters production in both non-grain sectors, is sufficiently greater than the growth of the terms-of-trade favoring textiles, which encourages production in textiles over agricultural commodities. Thus, weak deindustrialization should have been most severe when nominal wage growth was strongest and when the terms of trade were shifting most strongly in favor of agricultural commodities.

In summary, the predictions of the model are: strong deindustrialization, defined as a decrease in $\mathrm{L}_{\mathrm{T}}$, will result if the own wage in textiles increases; and weak deindustrialization, defined as a decrease in $\mathrm{L}_{\mathrm{T}} / \mathrm{L}$, will result if own wage growth in textiles increases sufficiently faster than the own wage growth in agricultural commodities.

\section{The Terms of Trade, Relative Prices, and the Own-Wage in Manufactures 1750-1913}

We divide the Indian deindustrialization experience over the century and a half between about 1750 and 1913 into three distinct epochs. Our interpretation of the fundamentals explaining deindustrialization within each of these epochs implies predictions regarding changes in Indian relative prices.

The first epoch, approximately 1750-1810, was one during which India lost its significant share of world textile markets to Britain. What was an important export sector in India at the beginning of the epoch became an important import-competing sector at the end. While that result can be explained by increasing cost competitiveness favoring Britain, superior factory technology was not yet the main force at work. Instead, we believe that it was reduced agricultural productivity in India that mattered most in this epoch. Grain prices rose and thus - in a relatively stable real wage subsistence economy where grain was the key consumption goodpushed up nominal wages economy-wide. Hence, the own wage rose in both tradable sectors, textiles and 
commodity production, damaging cost competitiveness there. ${ }^{18}$ Textiles would thus experience strong deindustrialization. To the extent that the price of textiles relative to commodities fell, the effect of reduced agricultural productivity would have fallen more heavily on textiles than commodities, a weak deindustrialization effect.

The second epoch, approximately 1810-1860, was one during which India lost much of its domestic textile market to Britain. This result can be explained by the combined influence of relatively rapid factorybased productivity advance in Britain and by increased world market integration, the latter driven by declining transport costs between the two trading partners, and to a free trade commitment for India on the part of her colonial rulers. The terms of trade moved to favor India and hurt her import competing manufacturing sector. The effects of the economic difficulties of the $18^{\text {th }}$ century were pretty much over, and the induced decline in Indian grain productivity had ceased.

The third epoch, approximately 1860-1913, was one during which the rate of deindustrialization slowed down and eventually reversed. Late in the epoch, India was "reindustrializing." This result can be explained by the subsidence in both the unbalanced productivity advance favoring European manufacturing and in the world transport revolution. The terms of trade no longer moved in India's favor and thus no longer served to penalize import competing manufacturing.

These predictions are largely confirmed by our new relative price and terms-of-trade evidence, which we plot in Figures 3-7. A full description of how we constructed the data can be found in the Appendix. The analysis which follows will focus on the first two epochs, when deindustrialization was most dramatic.

Let us first consider strong deindustrialization across the first two epochs combined, recalling that strong deindustrialization is defined as an absolute decline in the industrial workforce, driven in our model by the own wage. Figure 3 documents that between 1765 and 1810 the price of textiles relative to grains fell at a spectacular rate: by $1805-1810$, it was less than 20 percent of its $1765-1770$ level. The decline continued after 1810 , but at a much slower rate. Why the spectacular fall in $\mathrm{p}_{\mathrm{T}} / \mathrm{p}_{\mathrm{G}}$ in the late $18^{\text {th }}$ century, especially compared with the early $19^{\text {th }}$ century? The answer is that grain prices, while volatile in the short run, soared upwards in

\footnotetext{
${ }^{18}$ If this formal "cost competitiveness" and "own-wage" language seems awkward when applied to household spinners and weavers, think instead of the grain that could be bought with nominal earnings in those households.
} 
the long run. However, this did not serve to reduce real wages $\left(\mathrm{w} / \mathrm{p}_{\mathrm{G}}\right)$. Figure 1 shows that grain wages appear to have been largely stable following the early-mid $18^{\text {th }}$ century. ${ }^{19}$ Figure 4 presents the grain wage using an alternative series of grain prices and confirms this claim for roughly the same years, between the 1720 s and the 1810s. Nominal wages were thus driven up along with grain prices.

While there was great short-run volatility in the grain wage, a Lewis-like assumption about long run real wage stability seems to be reasonable for the first epoch. As a result, the own-wage in Indian manufacturing (Figure 5: w/p $\mathrm{p}_{\mathrm{T}}$ ) more than doubled between 1765 and 1810. Since there is no qualitative evidence suggesting significant productivity advance in Indian textiles and other manufacturing production during this epoch, ${ }^{20}$ we take this evidence as powerful support for the thesis that reduced agricultural productivity attendant on the dissolution of Mughal hegemony and more frequent droughts can indeed explain much of India's pre-1810 deindustrialization and loss of world markets. India lost much of its cost competitiveness as the own-wage in home manufacturing underwent that spectacular rise, and it was the rise in the price of non-tradable grains that pushed up the nominal wage to such high levels. Most of the secular rise in grain prices stopped after around 1810, and the upward pressure on nominal wages began to ease. Thus, conditions in the grain sector stabilized a bit in the second epoch, and the fall in $\mathrm{p}_{\mathrm{T}}$ dominated deindustrialization conditions in Indian manufacturing. The relative price $\mathrm{p}_{\mathrm{T}} / \mathrm{p}_{\mathrm{G}}$ fell (Figure 3 ), the own-wage $\mathrm{w} / \mathrm{p}_{\mathrm{T}}$ rose (Figure 5), and deindustrialization continued - but now driven mainly by exogenous world market forces.

Now let us consider weak deindustrialization across the first two epochs, recalling that it will be more intense when the own-wage in textiles is growing faster and when the intersectoral terms of trade is shifting most strongly in favor of agricultural commodities. Figure 5 shows $w / \mathrm{p}_{\mathrm{T}}$ doubling between 1770 and 1810 and more than doubling between 1810 and 1850 . Thus, own-wage growth was slightly stronger in the second epoch. Conversely, the terms of trade shift appears to be strongest in the first epoch. Figure 8 documents India's external terms of trade from 1800. It shows two big spikes in the second epoch, the first over the

\footnotetext{
${ }^{19}$ Note that Broadberry and Gupta's north India grain wage series contains no data points between 1690 and 1874 , so it is impossible to discern trends within the $18^{\text {th }}$ century from it.

${ }^{20}$ In any case, since agriculture was so huge, it must have dominated nation-wide labor scarcity conditions, not just those in manufacturing.
} 
decade of the $1810 \mathrm{~s}$ and the second over the decade of the $1850 \mathrm{~s}$. When the series is smoothed, the measured trend in the terms of trade favoring India (and thus penalizing the import competing sector) is very modest. In contrast, during the first epoch the intersectoral terms of trade between textiles and agricultural commodities (Figure 3: $\mathrm{p}_{\mathrm{T}} / \mathrm{p}_{\mathrm{C}}$ ) underwent a very sharp decline. By 1810 it was only 20 percent of its 1780 level, causing lost agricultural productivity to fall much more heavily on textiles than on agricultural commodities during that period. Indeed, the own wage in agricultural commodities actually fell during this period (Figure 5: w/ $\mathrm{p}_{\mathrm{C}}$ ). This pattern suggests that strong deindustrialization may well have been greater in the first epoch than in the second. In the first epoch, labor left textiles due to labor's demand for higher nominal wages and to a strong shift in the terms of trade favoring agricultural commodity exports and disfavoring textiles, while in the second epoch labor left mainly due to falling world textile prices.

If we take the own-wage in manufacturing as a critical indicator of cost competitiveness, and if England was India's main competitor in world markets, we can compare trends in the own-wage in textiles between the two as an indicator of relative productivity change. We must be cautious here, since a measured increase in the ratio of Indian to English w/ $\mathrm{p}_{\mathrm{T}}$ will understate the role of own-wage inflation to the extent that English productivity growth performance was superior to India even before the great factory boom. Our source for England is Gregory Clark (2004: Table 6 for nominal wages; Table 4 for grain and clothing prices), whose data allow us to construct the price of clothing relative the grain $\left(\mathrm{p}_{\mathrm{T}} / \mathrm{p}_{\mathrm{G}}\right)$ 1705-1865 and the own-wage in textiles $\left(\mathrm{w} / \mathrm{p}_{\mathrm{T}}\right)$. Figure 6 plots an index of the ratio of English $\mathrm{p}_{\mathrm{T}} / \mathrm{p}_{\mathrm{G}}$ to Indian $\mathrm{p}_{\mathrm{T}} / \mathrm{p}_{\mathrm{G}}$. The Indian series uses decadal averages due to the volatility of $\mathrm{p}_{\mathrm{G}}$ in India, and thus starts in 1775 , the end of the first decade for which we have data. The price of textiles relative to grains fell in both economies 1765-1850, but it fell five times faster in India due to the much bigger $\mathrm{p}_{\mathrm{G}}$ boom there. The index of British relative to Indian $\mathrm{p}_{\mathrm{T}} / \mathrm{p}_{\mathrm{G}}$ rose from 100 in 1775 to 228 by 1815, and again to 421 by 1845 . Grain prices rose almost four times faster in India than England, an event which we argue put greater upward pressure on wage costs in India than England, thus lowering the English own-wage in textiles relative to India. Indeed, the ratio of w/p $\mathrm{p}_{\mathrm{T}}$ in England relative to India fell from 100 in 1775, to 56 in 1815, and to 26 in 1845, as shown in Figure 7. More than half of that century fall was completed by 1805 , before the great flood of factory-produced textiles hit Indian markets in the second deindustrialization epoch. But even after 1810, it appears that some part of Indian 
deindustrialization was explained by poor productivity performance in grains: after all, $\mathrm{p}_{\mathrm{T}}$ was pretty much equalized between India and Britain, so the faster decline in India's $\mathrm{p}_{\mathrm{T}} / \mathrm{p}_{\mathrm{G}}$ implies a poorer productivity performance in grains there, and perhaps even compared with the rest of the periphery. If we had Indian data for 1705-1765, we think it would extend these trends backwards. After all, the English $\mathrm{p}_{\mathrm{T}} / \mathrm{p}_{\mathrm{G}} \mathrm{declined}$ only modestly between 1705 and $1765,{ }^{21}$ and $w / p_{\mathrm{T}}$ hardly changed at all. Our guess is that $\mathrm{p}_{\mathrm{T}} / \mathrm{p}_{\mathrm{G}}$ fell sharply in India given that $\mathrm{p}_{\mathrm{G}}$ about doubled between 1704-1706 and 1764-1766. This added evidence seems to point to reduced agricultural productivity, with its roots in the decline of the Mughal empire and in the secular rise in drought frequency, as the central cause of Indian deindustrialization in the $18^{\text {th }}$ and even in the early $19^{\text {th }}$ century.

\section{Indian Relative Price Trends Compared with the Rest of the Periphery}

Deindustrialization appeared everywhere around the $19^{\text {th }}$ century periphery, and globalization plays a major role in each region's historiography. Here we ask whether $19^{\text {th }}$ century India faced a big or a small deindustrializing global price shock compared with other parts of the periphery. If India's global price shock was small, it follows that domestic supply-side deindustrialization forces were relatively important in India compared to other parts of the periphery.

Figure 8 shows that India underwent a significant improvement in its terms of trade from 1800 to the mid-1820s, followed by a collapse, and then a significant rise again up to the early 1860 s. Over the halfcentury between $1800-1804$ and $1855-1859$, India's terms of trade rose only 28.6 percent, or less than 0.5 percent per annum. In contrast, the Egyptian terms of trade rose by two and a half times between 1820-1824 and 1855-1859, or 2.7 percent per annum (Figure 9); the Ottoman terms of trade increased by two and a half times between 1815-1819 and 1855-1859, or 2.4 percent per annum (Figure 10); and the Latin American terms of trade increased by 1.7 times between 1820-1824 and 1855-1859, or 1.7 percent per annum (Figure 11).

\footnotetext{
${ }^{21}$ Furthermore, the English terms of trade rose over those sixty years (Mitchell and Deane 1962: Table 14, 330).
} 
In short, it appears external price shocks facing India were quite modest compared to the rest of the periphery. ${ }^{22}$ Yet, Indian historians discuss deindustrialization more than do historians of other poor periphery regions. This suggests that domestic supply side conditions played a far more important role in accounting for deindustrialization in India than elsewhere.

\section{Conclusions}

India deindustrialized between 1750 and 1860, and two main epochs, with very different deindustrialization causes, distinguish that century. The first epoch runs from about 1750 to 1810 and was a direct result of poor climate conditions and an indirect result of the dissolution of the Mughal Empire. The deterioration in climate conditions lowered agricultural productivity, raised grain prices, and thus increased nominal wages in home manufacturing, like textiles, lowering India's competitiveness with England and other world textile producers. Furthermore, as central authority waned, these forces were strengthened: revenue farming expanded, the rent burden increased, warfare raised the price of agricultural inputs, and regional trade within the sub-continent declined, all serving to drive down the productivity of foodgrain agriculture still further. So grain prices had another reason to rise, and given that ordinary workers lived near subsistence, the nominal wage rose even faster, hurting India's competitiveness in the export market all the more. India thus lost ground to Britain in the world textile market during a period when most British production was still carried out using the cottage system. Additionally, the intersectoral terms of trade moved against textiles, encouraging a shift to agricultural commodity production. India's share of world industrial production fell faster than in any other part of the non-European world. During the second epoch, running from about 1810 to 1860 , productivity advance resulting from the adoption of the factory system drove down the relative price of textiles world-wide, a trend that was magnified as a world transport revolution lowered the price of textiles even further everywhere in the periphery. Thus, while the productivity of Indian agriculture stopped its decline during this period, under the relative security of Company rule and reinforced by a cessation in the secular rise

\footnotetext{
${ }^{22}$ Terms of trade increases up to the 1860s were also much bigger for Indonesia, Italy and Spain. In addition, after the 1840s their increase was much bigger for Japan and the Mideast (Williamson 2005).
} 
in drought frequency, and while the rise in grain prices slowed down and then stabilized, the relative price of grain continued to rise. ${ }^{23}$ By 1860 , India had completed a century-long two-part transition from being a net exporter to a net importer of textiles. A secular rise in the terms of trade stopped, turned around, and started a long run fall that lasted until the late 1930s. A deterioration in the terms of trade meant that the import competing sector (textiles) was no longer being penalized by unfavorable external price shocks. By the late $19^{\text {th }}$ century, India's deindustrialization was over, and the country began a period of slow reindustrialization.

\footnotetext{
${ }^{23}$ After 1860 , global trade in grains changed conditions considerably. Thus, the assumption that grains were non-tradable is increasingly untenable as the late $19^{\text {th }}$ century concludes. We think cheap imported grains (and railroad development within India) may have played a role in lowering the own wage in manufacturing after the 1860s or 1870s, and thus may have contributed to reindustrialization in India.
} 


\section{References}

Muzaffar Alam (1986), The crisis of empire in Mughal North India : Awadh and the Punjab, 1707-48 (Delhi:

Oxford University Press).

Robert C. Allen (2001), "Real Wages in Europe and Asia: A First Look at the Long-Term Patterns,” Oxford University, unpublished (August).

Amiya Bagchi (1976a), Deindustrialization in India in the Nineteenth Century: Some Theoretical Implications, Journal of Development Studies 12 (October): 135-64.

Amiya Bagchi (1976b), "Deindustrialization in Gangetic Bihar 1809-1901,” in B. De et al., Essays in Honour of Prof. S. C. Sarkar (New Delhi: People's Publishing House).

Paul Bairoch (1982), “International Industrialization Levels from 1750 to 1980," Journal of European Economic History 11 (Fall): 269-333.

Christopher Bayly (1983). Rulers, townsmen, and bazaars : north Indian society in the age of British expansion, 1770-1870 (Cambridge: Cambridge University Press).

Lance Brannan, John McDonald and Ralph Schlomowitz (1994), ATrends in the Economic Well-Being of South Indians under British Rule: The Anthropometric Evidence,” Explorations in Economic History 31 (April): 225-60.

Stephen Broadberry and Bishnupriya Gupta (2005), "The Early Modern Great Divergence: Wages, Prices and Economic Development in Europe and Asia, 1500-1800," unpublished paper, University of Warwick (February).

K. N. Chaudhuri (1978), The Trading World of Asia and the English East India Company, 1660-1760 (Cambridge: Cambridge University Press).

K. N. Chaudhuri (1983), "Foreign Trade and Balance of Payments (1757-1947)," in D. Kumar and M. Desai (eds.), The Cambridge Economic History of India, II (Cambridge: Cambridge University Press).

Benoy Chowdhury (1964), Growth of Commercial Agriculture in Bengal (Calcutta: R.K. Maitra).

Colin Clark (1950), Conditions of Economic Progress. $2^{\text {nd }}$ Ed. (London: Macmillan). 
Gregory Clark (2004), “The Condition of the Working-Class in England, 1200-2000: Magna Carta to Tony Blair," mimeo. Department of Economics, UC-Davis.

Charles Darwin (1972), The Origin of the Species (London: Dent and Sons, 1972 edn.)

Phyllis Deane and W. A. Cole (1967), British Economic Growth, 1688-1959: Trends and Structure (Cambridge: Cambridge University Press, $2^{\text {nd }}$ ed.).

Jan de Vries (1994), “The Industrial Revolution and the Industrious Revolution,” Journal of Economic History 54 (June): 249-70.

Romesh Dutt (1960), The Economic History of India, vol I, Under Early British Rule, 1757-1837 (2 vols; $2^{\text {nd }}$ ed.; London 1906; repr. Delhi: Government of India Publications Division).

Tim Dyson (ed.) (1989), India's Historical Demography: Studies in Famine, Disease and Society (London: Curzon Press).

Javier Cuenca Esteban (2001), "The British balance of payments, 1772-1820: India transfers and war finance," Economic History Review LIV (1): 58-86.

Holden Furber (1948), John Company at Work: A Study of European Expansion in India in the Late Nineteenth Century (Cambridge, Mass.: Harvard University Press).

Alexander Gerschenkron (1962), Economic Backwardness in Historical Perspective (Cambridge, Mass.: Harvard University Press).

Richard Grove (1997), Ecology, Climate and Empire: Colonialism and Global Environmental History, 14001940 (Cambridge: White Horse Press).

Richard Grove, Vinita Damodaran and Satpal Sangwan (eds.) (1998), Nature and the Orient: The Environmental History of South and Southeast Asia (Delhi: Oxford University Press).

Richard H. Grove and John Chappell (2000), “El Niño Chronology and the History of Global Crises During the Little Ice Age," in R. H. Grove and J. Chappell (eds.), El Niño - History and Crisis: Studies from the Asia-Pacific Region (Cambridge: White Horse Press): 5-34.

Irfan Habib (1975), “Colonialization of the Indian Economy, 1757-1900," Social Scientist 32 (3): 23-53. Irfan Habib (ed.) (1977), The Cambridge Economic History of India (Cambridge: Cambridge University Press). 
Irfan Habib (1985) "Studying a Colonial Economy without Perceiving Colonialism," Modern Asian Studies 119 (3): 355-81.

Irfan Habib (2003) “The Eighteenth Century in Indian Economic History," in P.J. Marshall ed. The Eighteenth Century in Indian History: Evolution or Revolution (Oxford: Oxford University Press).

Peter Harnetty (1991), “'Deindustrialization' Revisited: The Handloom Weavers of the Central Provinces of India c.1800-1947," Modern Asian Studies 25 (3): 455-510.

Joseph Inikori (2002), Africans and the Industrial Revolution in England (Cambridge: Cambridge University Press).

Ronald W. Jones (1971), "A Three-Factor Model in Theory, Trade, and History," in J. N. Bhagwati et al. (eds), Trade, Balance of Payments, and Growth (Amsterdam: North-Holland).

Cezary Kapuscinski (2000), “Agricultural Productivity in India: The Role of Climate Information in Forecasting Yields of Foodgrains," in R. H. Grove and J. Chappell (eds.), El Niño - History and Crisis: Studies from the Asia-Pacific Region (Cambridge, England: White Horse Press): 196-223.

Paul Krugman and Anthony Venables (1995), "Globalization and the Inequality of Nations," Quarterly Journal of Economics 110 (November): 857-80.

David Landes (1998), The Wealth and Poverty of Nations (New York: Norton).

Roland Landinois (1989), “Deserted Villages and Depopulation in Rural Tamil Nadu c.1780- c.1830,” in T. Dyson (ed.), India's Historical Demography: Studies in Famine, Disease and Society (London: Curzon Press): 16-48.

W. Arthur Lewis (1954), “Economic Development with Unlimited Supplies of Labour,” Manchester School of Economics and Social Studies 22: 139-91.

W. Arthur Lewis (1978), The Evolution of the International Economic Order (Princeton, NJ: Princeton University Press).

Angus Maddison (2001), The World Economy: A Millennial Perspective (Paris: OECD). Marshall (1987), Bengal: the British bridgehead (Cambridge: Cambridge University Press).

P.J. Marshall (ed.) (2003), The Eighteenth Century in Indian History: Evolution or Revolution? (New Delhi: Oxford University Press). 
Robert Martin (1838), The history, antiquities, topography, and statistics of eastern India (London: H.W.

Allen \& Co.).

Karl Marx (1977[1867]), Capital, Volume 1, translated by B. Fowkes (New York: Vintage Books).

Brian R. Mitchell and Phyllis Deane (1962), Abstract of British Historical Statistics (Cambridge: Cambridge University Press).

Joel Mokyr (1993), The British Industrial Revolution: An Economic Perspective (Boulder, Col.: Westview Press).

Shireen Moosvi (2000), “The Indian Economic Experience 1600-1900: A Quantitative Study,” in K. N. Panikkar, T. J. Byres, and U. Patnail (eds.), The Making of History: Essays Presented to Irfan Habib (New Delhi: Tulika).

Shireen Moosvi (2002), "Studying a Colonial Economy - Without Perceiving Colonialism,” in I. Habib (ed.), Essays in Indian History (London: Anthem Press).

Morris D. Morris (1969), "Trends and tendencies in Indian economic history," in Indian Economy in the Nineteenth Century: A Symposium (Delhi: Indian Economic and Social History Association).

Morris D. Morris (1983), “The growth of large-scale industry to 1947," in D. Kumar and M. Desai (eds.), The Cambridge Economic History of India, II (Cambridge: Cambridge University Press).

Radhakamal Mukerjee (1939), The Economic History of India: 1600-1800 (London: Longmans, Green and Company).

Jawaharlal Nehru (1947), The Discovery of India (London: Meridian Books).

Patrick K. O’Brien Ed. (1999), Oxford Atlas of World History (New York: Oxford University Press).

Şevket Pamuk (1987), The Ottoman Empire and European Capitalism, 1820-1913: Trade, Investment and Production (Cambridge: Cambridge University Press).

Prasannan Parthasarathi (1998), A Rethinking Wages and Competitiveness in the Eighteenth Century: Britain and South India," Past and Present 158 (February): 79-109.

Om Prakash (2005), “’’The Great Divergence: Evidence from Eighteenth Century India.” Paper presented at the GEHN Conference on Imperialism, Istanbul (September 11-12). 
Tapan Raychaudhuri (1983), “The mid-eighteenth-century background,” in D. Kumar and M. Desai (eds.), The Cambridge Economic History of India, II (Cambridge: Cambridge University Press).

Tirthankar Roy (2000), The Economic History of India 1857-1947 (Delhi: Oxford University Press).

Tirthankar Roy (2002), “Economic History and Modern India: Redefining the Link,” Journal of Economic Perspectives 16 (Summer): 109-30.

Saif Shah Mohammed and Jeffrey G. Williamson (2004), "Freight Rates and Productivity Gains in British Tramp Shipping 1869-1950," Explorations in Economic History 41 (April): 172-203.

Colin Simmons (1985), “'Deindustrialization', Industrialization, and the Indian Economy, c. 1850-1947," Modern Asian Studies 19 (3): 593-622.

Daniel Thorner (1962), “Deindustrialization in India 1881-1931,” in D. Thorner and A. Thorner (eds.), Land and Labour in India (Bombay: Asia Publishing House).

Jeffrey G. Williamson (2005), “Globalization, Deindustrialization and Underdevelopment in the Third World Before the Modern Era," the Figuerola Lecture, to be presented at Carlos III University, Madrid (October 6).

Stanley Wolpert (1989), A New History of India, (New York: Oxford University Press). 


\section{Appendix: The Data}

Wages. The nominal wage series for India comes from R. Mukerjee (1939), The Economic History of India: 1600-1800 (London: Longmans, Green and Company) and S. Broadberry and B. Gupta (2005), "The Early Modern Great Divergence: Wages, Prices, and Economic Development in Europe and Asia, 1500-1800" (Working Paper, University of Warwick, February). They mostly reflect conditions in North India. Linear interpolation was used to produce annual estimates from the data, which are reported for the years 1595,1600 , $1616,1623,1637,1640,1690,1729,1750,1807,1816,1850$, and 1870.

Grain Prices. The grain price index incorporates data from several locations for four key foodgrains in India: bajra, jowar, rice, and wheat. The index takes an unweighted average across all locations and all grain price quotes available for any given year. The sources are as follows. Prices of bajra, jowar, and wheat 1700-1750 from the Amber region (near present day Jaipur) are from S. Nurul Hasan, K.N. Hasan, and S.P. Gupta (1987), "The Pattern of Agricultural Production in the Territories of Amber (c. 1650-1750)," in S. Chandra ed. Essays in Medieval Indian Economic History (Delhi: Munshiram Manoharlal Publishers). Wheat prices at Delhi 17631835, rice prices at Madras 1805-1850, wheat and jowar prices at Pune 1830-1863, and wheat, jowar, and bajra prices at Agra City 1813-1833 are from A. Siddiqi (1981), "Money and Prices in the Earlier Stages of Empire," Indian Economic and Social History Review (vol. 18, nos. 3-4). Prices of bajra, jowar, and wheat quoted at Pune 1795-1830 are from V.D. Divekar (1989), Prices and Wages in Pune Region in a Period of Transition, 1805-1830 A.D. (Pune: Gokhale Institute Monograph No. 29, Gokhale Institute of Politics and Economics). Rice and wheat prices at Fatehpur (in present-day Uttar Pradesh) come from C. W. Kinloch (1852), Statistical Report of the District of Futtehpore, July 1851 (Calcutta: F. Carbury). Wheat and rice prices at Cawnpore (present-day Kanpur) are from Sir Robert Montgomery (1849), Statistical Report of the District of Cawnpoor (Calcutta: J.C. Sherriff). The price of rice at Calcutta 1712-1760 are from K.N. Chaudhuri (1978), The Trading World of Asia and the English East India Company (Cambridge: Cambridge University Press).

Textile Prices. The bulk of the 18th and 19th century Indian manufacturing sector was involved in producing cotton textiles. Our textile price series $1765-1820$ is constructed by taking the unweighted average of the 
import prices of muslin and calico piece goods reported at London and collected by Javier Cuenca Esteban (underlying his “The British balance of payments, 1772-1820: India transfers and war finance,” Economic History Review LIV February 2001: 58-86, and sent to us by the author). Since these manufactured goods had high value relative to their bulk, transport costs were a small fraction of their selling price in London by the late $18^{\text {th }}$ century. The $1820-1850$ India textile price series is taken to be the price of cotton piece goods reported in D. B. and W. S. Dodd (1976), Historical Statistics of the United States from 1790-1970 (University, Ala.: University of Alabama Press).

Export Commodity Prices. The five key export commodities produced in India during most of the $19^{\text {th }}$ century were indigo, raw silk, raw cotton, opium, and sugar. Our export commodity price index was created by weighting the prices of these five commodities by their export shares as reported in K.N. Chaudhuri (1983), "Foreign Trade and Balance of Payments (1757-1947)," in D. Kumar ed. The Cambridge Economic History of India v.2 (Cambridge: Cambridge University Press), hereafter Chaudhuri. The Chaudhuri export shares only begin in 1811, and these (fixed) 1811 shares were used to weight prices in earlier years. Since $18^{\text {th }}$ century price data for each of the five component commodities begins in different years prior to 1795, the export commodity price index weights the available prices by their 1811 export shares in a total export that includes only those commodities for which prices are available. Thus, the weights used in each year always add up to one. The coverage of the component series is as follows: indigo, 1782-1850; raw cotton, 1790-1850; raw silk, 1782-1850; opium, 1787-1850; sugar, 1795-1850. The indigo data is composed of British import prices of Indian indigo collected by Cuenca Estenban for 1782-1820 and for 1821-1850 British import prices of indigo in general from the microfilmed supplement to A. D. Gayer, W. W. Rostow, and A. J. Schwartz (1975), The Growth and Fluctuation of the British Economy, 1790-1850 (Hassocks: Harvester Press), hereafter GRS, for 1821-1850. Raw cotton data are also British import prices of Indian cotton from Cuenca Estenban for 17901831 and British import prices of raw cotton in general from GRS for 1832-1850. Raw silk is composed of British import prices of Bengal silk from Cuenca Esteban for 1782-1820 and British import prices of raw silk in general from GRS for 1821-1850. Opium price data are taken from the Calcutta auction price of export opium recorded in Great Britain, Sessional Papers of the House of Commons (1895: vol. XLII), Final Report of the Royal Commission on Opium, Part II Historical Appendices, Appendix B 62-63 for 1787-1840 and from 
the average revenue yielded per chest of export opium found in J. Richards (2002), "Opium Industry in British India," Indian Economic and Social History Review (vol. 39, nos. 2-3) for 1841-1850. Sugar prices for 17951820 are British import prices of Indian brown sugar from Cuenca Esteban and data for 1820-1850 are British import prices of sugar in general from GRS.

Terms of Trade. The net barter terms of trade for India 1800-1913 are constructed two ways, labeled Chaudhuri (1800-1850) and BCW (1800-1913) in Figure 8. The export prices for both methods are the same. From 1800 to1870, prices for cotton piece goods, raw cotton, raw silk, opium, indigo, and sugar are weighted by the export shares found in Chaudhuri. Individual commodity price series are as described above in the textile and commodity price sections. The import price component of the Chaudhuri terms of trade series was calculated using import shares found in Chaudhuri. Imports were bar iron, manufactured copper, raw wool, wine, cotton sheeting, and raw cotton, and their prices came from GRS, with the exception of cotton sheeting, which came from Historical Statistics of the United States from 1790-1970. The import price component of the BCW terms of trade series for 1800-1870 followed the method used in the BCW database, compiled by Jeffrey Williamson and his collaborators Chris Blattman and Michael Clemens. U.S. prices for textiles, metals, building materials, and chemicals and drugs are taken from the Historical Statistics of the United States from $1790-1970$ and are weighted using the fixed weights $0.55,0.15,0.075$, and 0.075 . The $\mathrm{BCW}$ terms of trade series is continued to 1913 by use of the India terms of trade series found in the BCW database and appendix. This 1870-1913 series, along with terms of trade series for Latin America, the Ottoman Empire, and Egypt, was first reported in Clemens and Williamson "Where did British Foreign Capital Go?" NBER Working Paper 8028, National Bureau of Economic Research, Cambridge, Massachusetts (December 2000) which has since been published as "Wealth Bias in the First Global Capital Market Boom 1870-1913," Economic Journal vol. 114 (April 2004): 311-44. The BCW appendix describes their construction and it is available from Williamson upon request. 
Table 1

\begin{tabular}{lcr}
\multicolumn{2}{r}{$\begin{array}{c}\text { Population Dependent on Industry In Gangetic Bihar } \\
\text { (in percent) }\end{array}$} \\
& $1809-1813$ & 1901 \\
Assumption A & 28.5 & 8.5 \\
Assumption B & $21.6^{*}$ & 8.5
\end{tabular}

Source: Bagchi (1976b): Tables 1-5.

Note: Under Assumption A, each spinner supports only him or herself, and under Assumption B, each spinner also supports one other person.

Under both assumptions, non-spinners are assumed to support the survey's modal family size (5).

* Bagchi reports 18.6, but this appears to be a mistake. See the breakdown in Table 2.

Table 2

Population of Gangetic Bihar Dependent on Different Occupations (in percent)

$1809-1813$

1901

Spinners

10.3

Weavers

2.3

Other Industrial

9.0

7.2

TOTAL

$21.6^{*}$

8.5

Source: Bagchi (1976b): Tables 1-5.

* Bagchi reports $18.6 \%$, but this appears to be a mistake. 
Table 3

\section{World Manufacturing Output 1750-1938}

(in percent)

$\begin{array}{rrrrr}\text { Year } & \text { India } & \text { China } & \begin{array}{c}\text { Rest of the } \\ \text { Periphery }\end{array} & \begin{array}{c}\text { Developed } \\ \text { Core }\end{array} \\ 1750 & 24.5 & 32.8 & 15.7 & 27.0 \\ 1800 & 19.7 & 33.3 & 14.7 & 32.3 \\ 1830 & 17.6 & 29.8 & 13.3 & 39.5 \\ 1880 & 2.8 & 12.5 & 5.6 & 79.1 \\ 1913 & 1.4 & 3.6 & 2.5 & 92.5 \\ 1938 & 2.4 & 3.1 & 1.7 & 92.8\end{array}$

Source: Simmons 1985, Table 1, p. 600, based on Bairoch 1982, Tables 10 and 13, pp. 296 and 304.

Note: India refers to the entire subcontinent. 
Figure 1

Grain Wages in India 1600-1938 $(1600=100)$

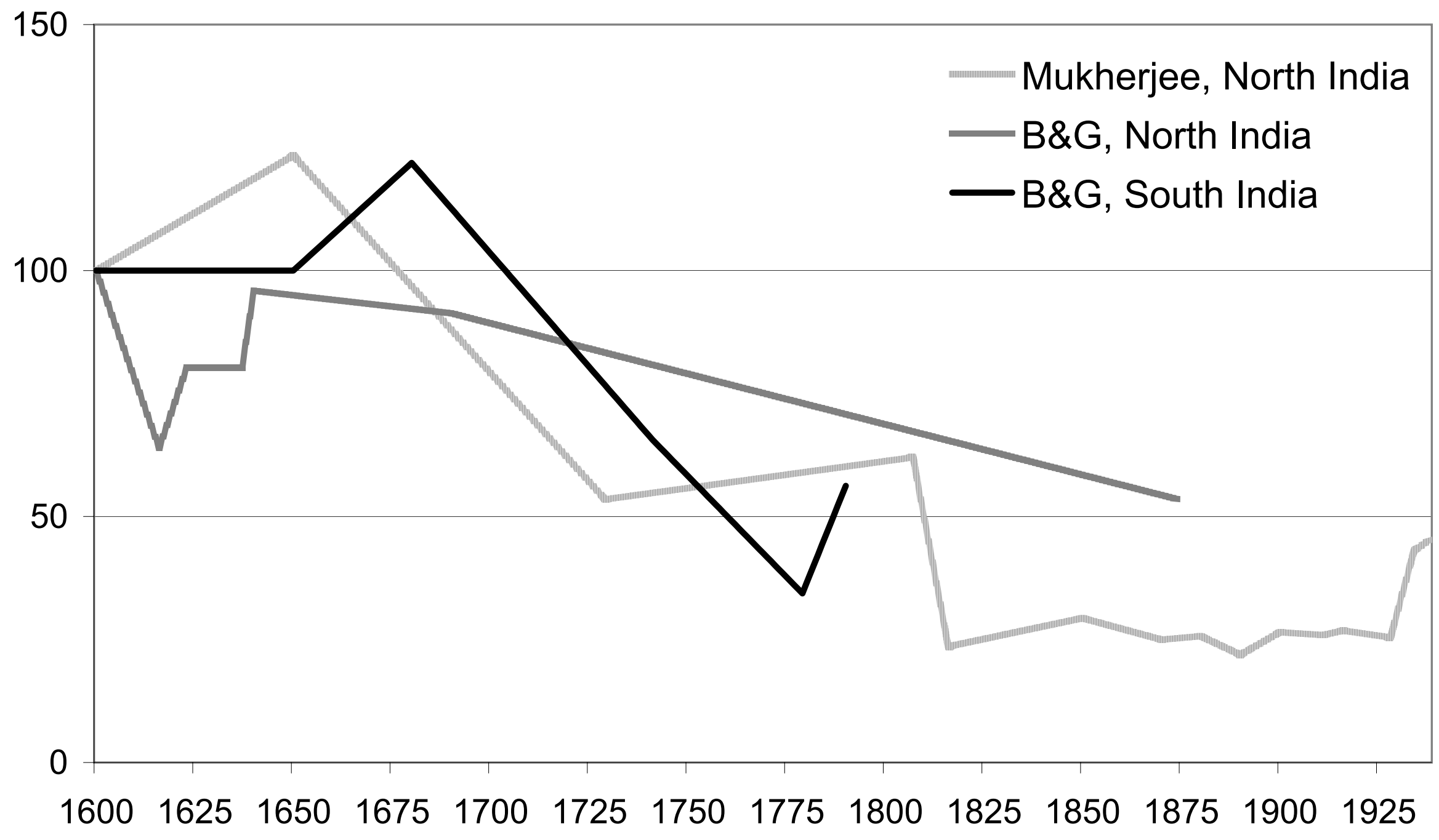


Figure 2

50-Year Centered Moving Average of the Occurrence of a Drought Year in India 1550-1900

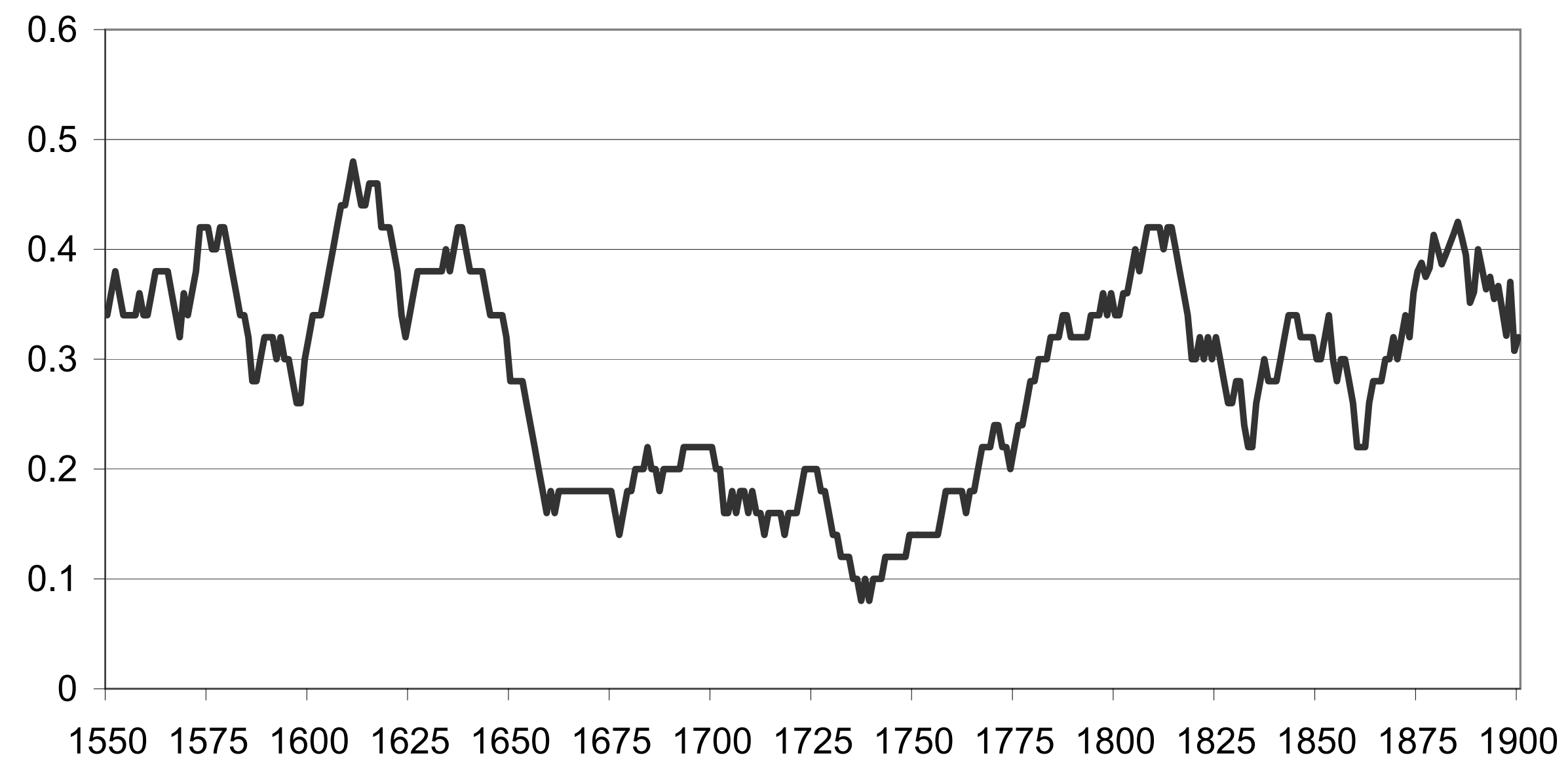


Figure 3

Relative Prices of Tradeables $(1800=1)$

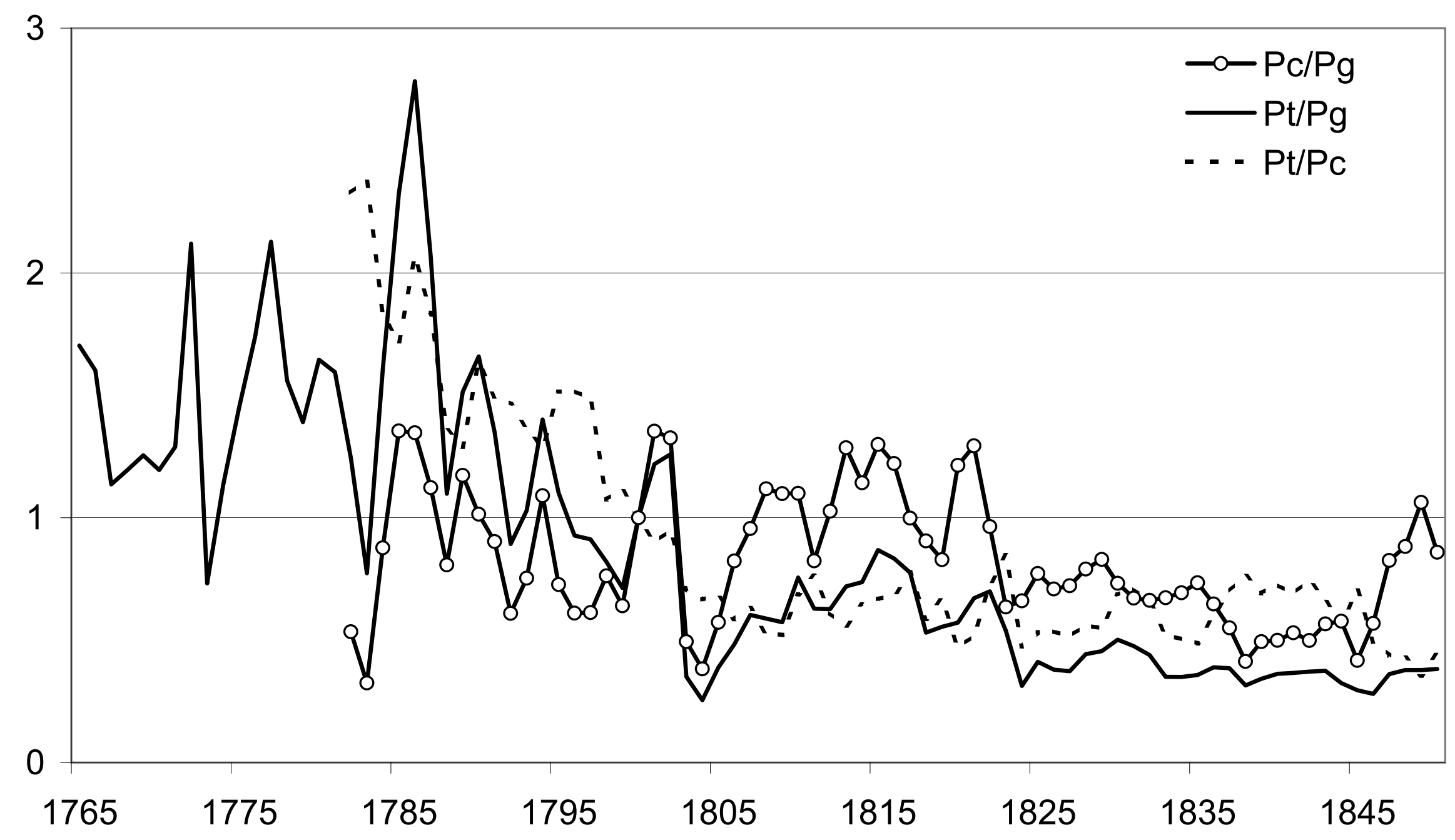


Figure 4

Grain Wage in North India 1700-1850 (1800=1)

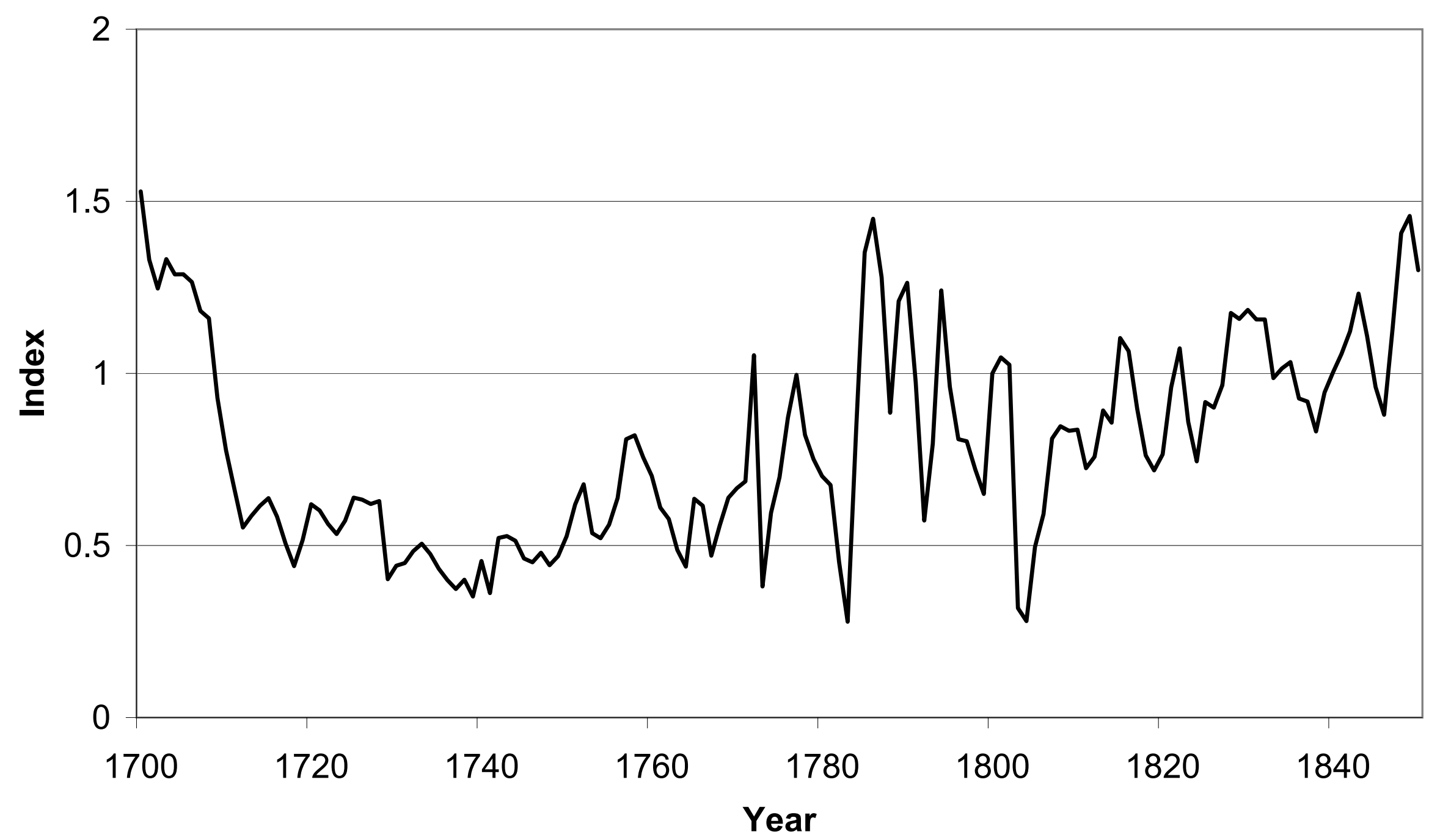


Figure 5

Indian Own Wages in Textiles and Agricultural

Commodities $(\mathbf{1 8 0 0}=1)$

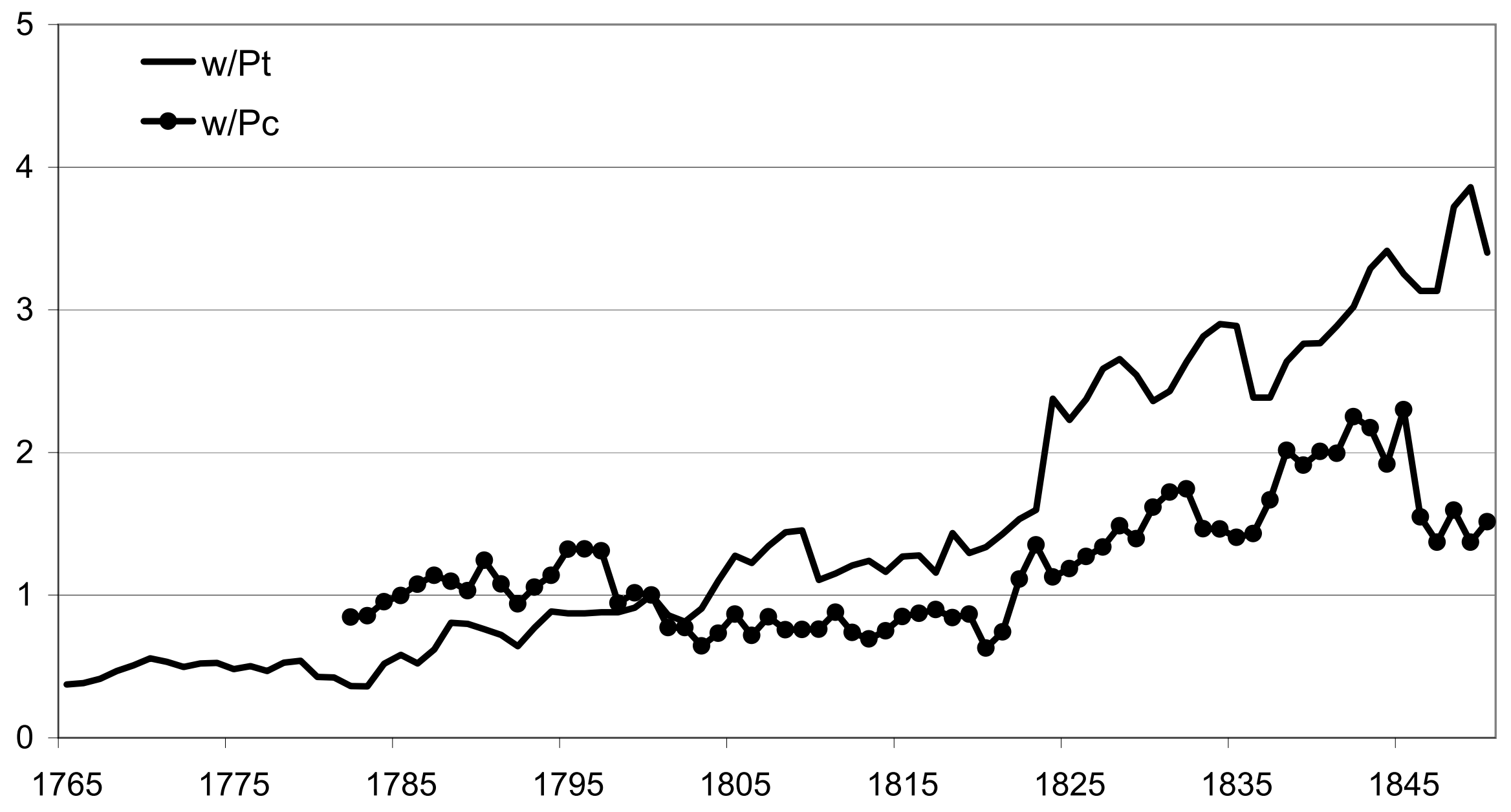




\section{Figure 6}

\section{Grain Price of Textiles in England and India (1775=100)}

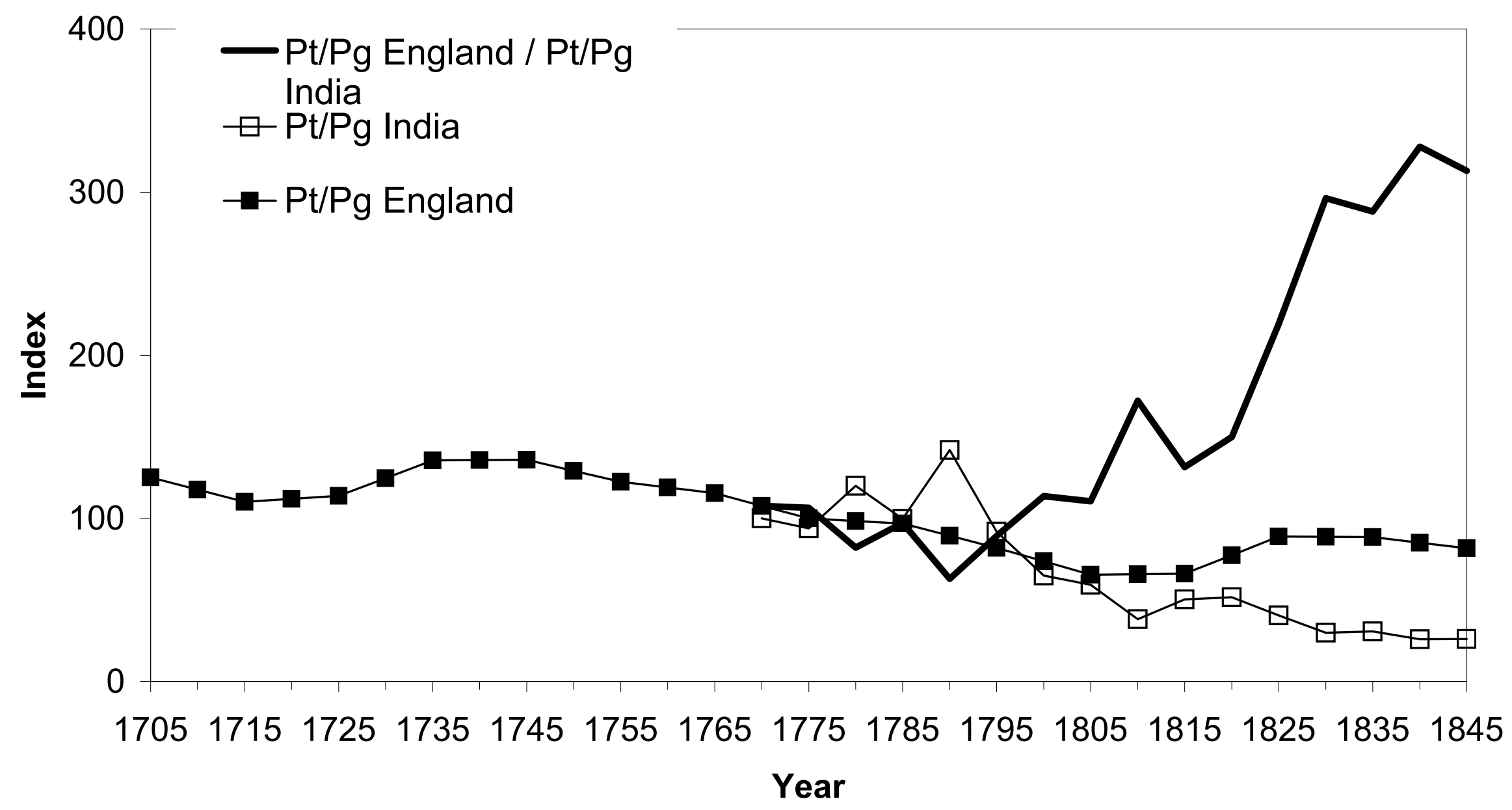


Figure 7

Textile Own Wages in England and India (1775=100)

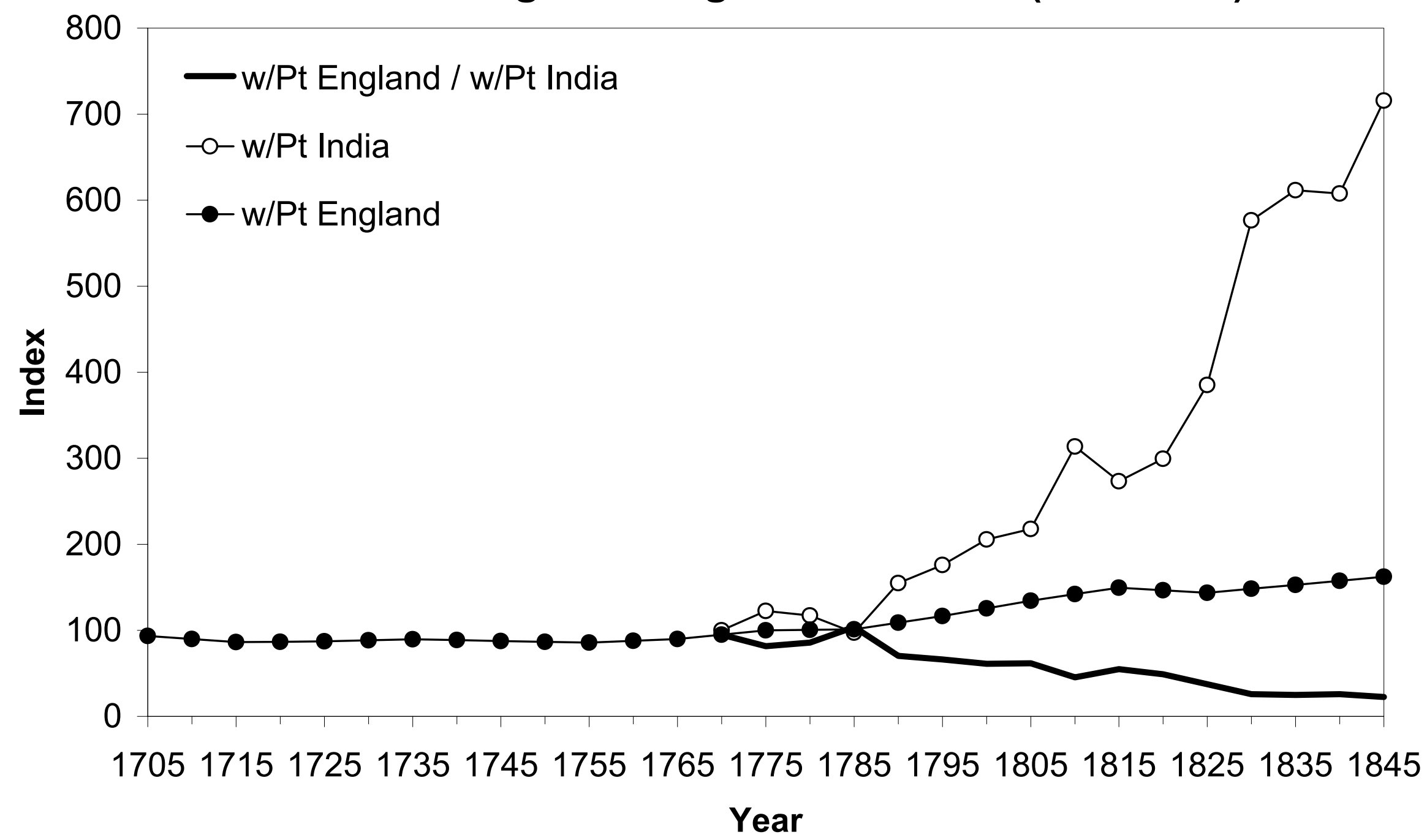


Figure 8

India's Terms of Trade 1800-1913

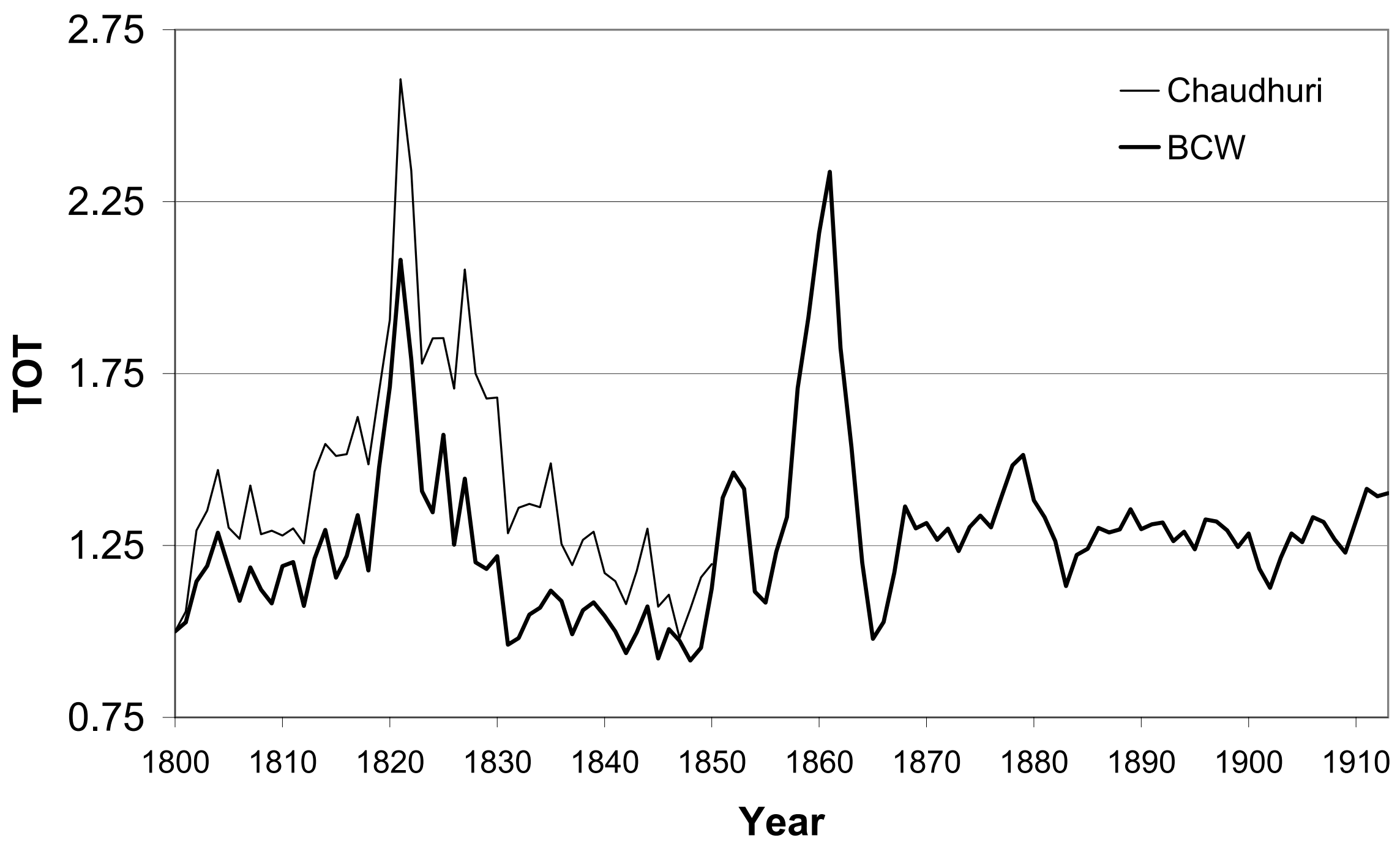


Figure 9

Egypt's Terms of Trade 1820-1913 $(1880=100)$

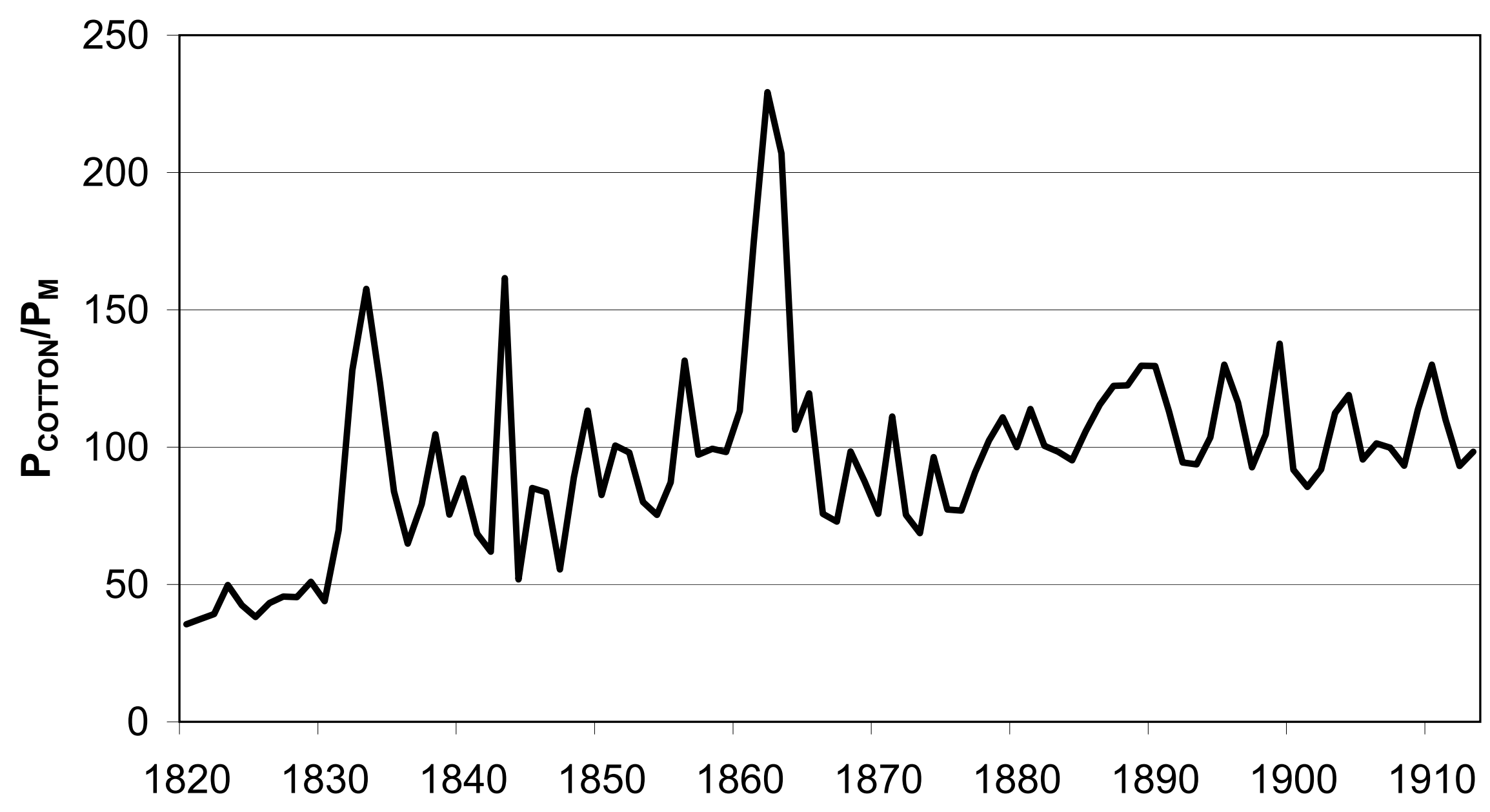


Figure 10

Ottoman Terms of Trade 1815-1913 (1858=100)

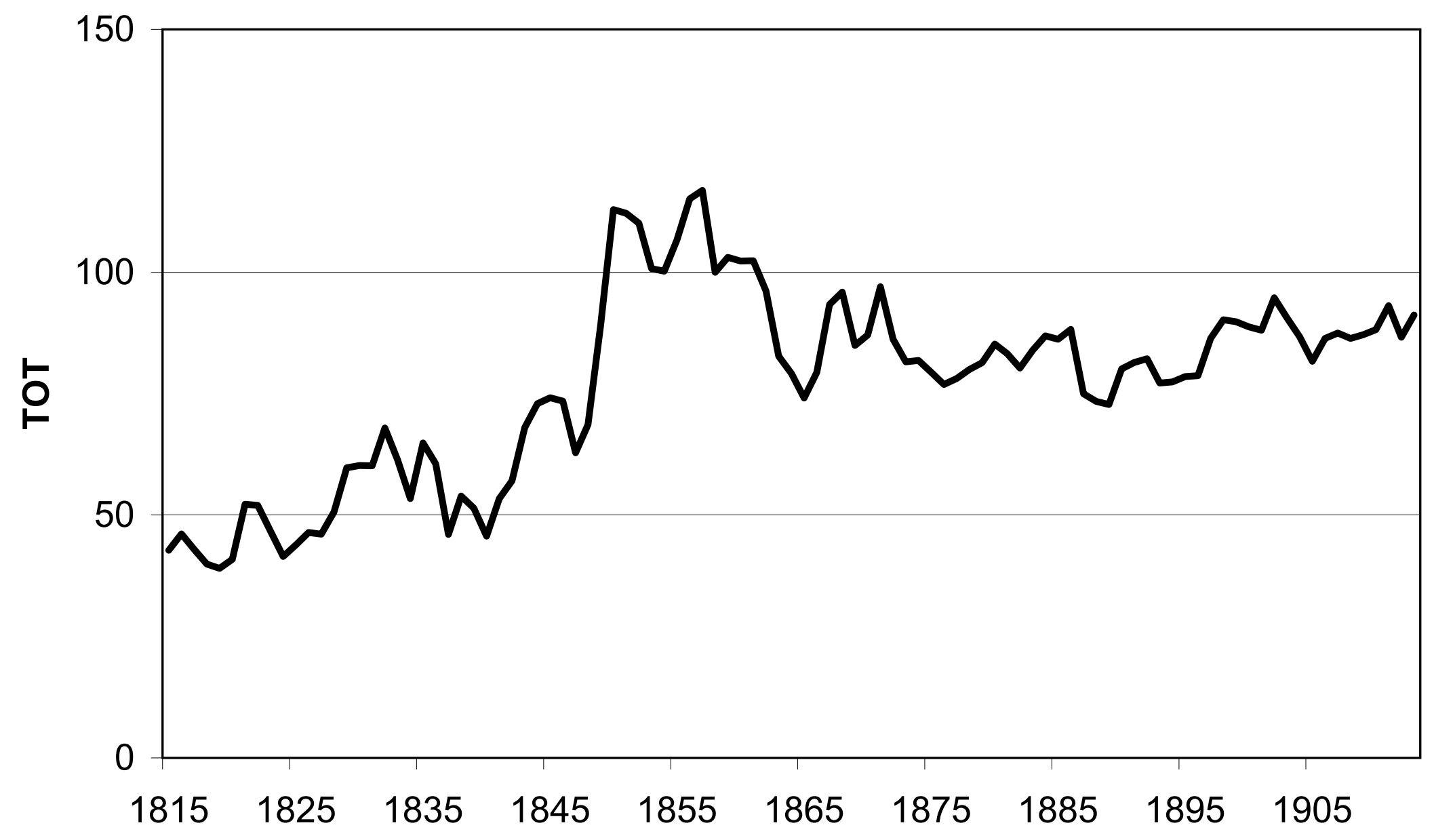


Figure 11

Latin American Terms of Trade 1820-1950

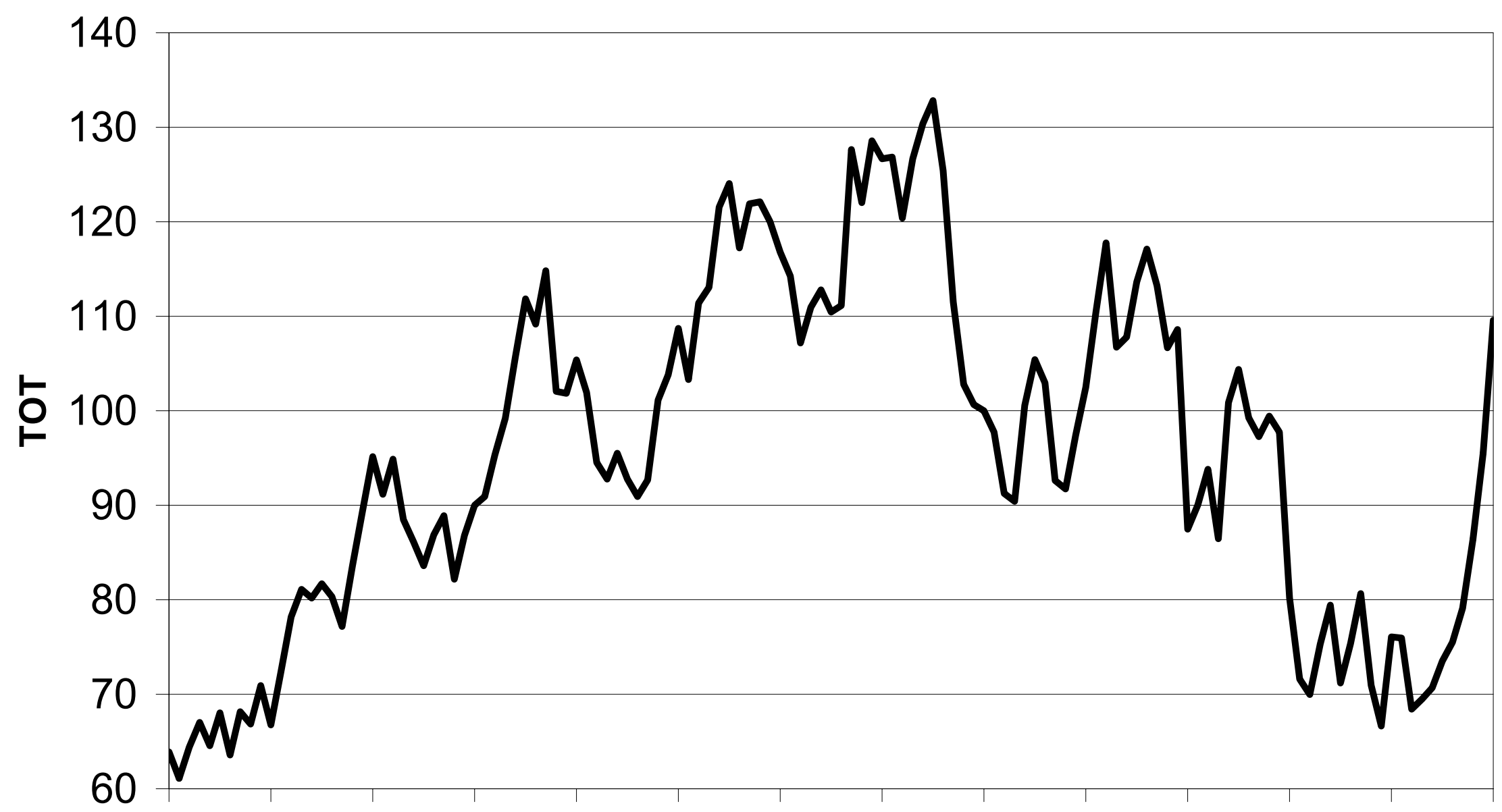

18201830184018501860187018801890190019101920193019401950 